\title{
Using and abusing a torrential urban river: the Wien River before and during industrialization
}

\author{
Gudrun Pollack $^{1} \cdot$ Sylvia Gierlinger ${ }^{1} \cdot$ Gertrud Haidvogl $^{2}$ • \\ Verena Winiwarter ${ }^{1}$
}

Received: 11 June 2015/ Accepted: 9 July 2016/Published online: 26 September 2016

(C) The Author(s) 2016. This article is published with open access at Springerlink.com

\begin{abstract}
The Wien River is the largest tributary of the Viennese Danube and was a center of urban production during industrialization. It's highly dynamic flow regime with small average discharge as well as recurrent big, fast floods posed challenges to its use. In this study we focus on the role of this urban watercourse for supplying water to crafts and industries and for wastewater discharge in the 19th century. Animal slaughtering, tanning, dyeing, textile printing, beer brewing, and chemical industry as main water demanding and polluting crafts were investigated. Their location in the catchment was determined and they were systematized by their needs of water and types of pollutants released into the river. Spatial distribution patterns of these industries from the end of the 18th to the end of the 19 th century show a complex picture in terms of water supply and waste water discharge. We found very distinct patterns for different sections of the river as well as for different crafts and could observe a change over the time period investigated. Only few types of businesses lied close to the Wien River which can, to some extent, be explained with the high risk of flooding. Groundwater played a more important role for water supply while the main function of the river was wastewater discharge. Spatial distribution of crafts and industries, and changes in locations resulted from an interplay of environmental and social factors. Availability of surface waters, water supply, and discharge infrastructure (wells, pipelines, sewers) seem to have been important for the choice of location for production sites. Regulations concerning the exertion of industries, economic factors and technological innovation also played a role in the development of the observed spatial pattern.
\end{abstract}

Keywords Vienna - Wien river - Industrialization - Urban rivers · Commercial use · Spatial distribution

Gudrun Pollack

gudrun.pollack@aau.at

1 Institute of Social Ecology, Alpen-Adria -Universität Klagenfurt, Schottenfeldgasse 29, 1070 Vienna, Austria

2 Institute of Hydrobiology and Aquatic Ecosystem Management, University of Natural Resources and Life Sciences Vienna (BOKU), Gregor Mendel Str. 33, 1180 Vienna, Austria 


\section{Introduction}

Industrialization, urbanization and hygiene have been recognized as main factors that affected the history of urban rivers in Europe (e.g. Barles 2012). During the 19th century, urban rivers were transformed because of economic development, population growth, hygienic improvements and new practices of flood protection; all made possible, necessitated or enhanced by the shift to coal as main energy source. Following Geddes (1915) as an early forerunner, Lewis Mumford stressed the eminent role of this new energetic basis for the development of cities (Mumford 1956). In a recent study on Vienna and its hinterland, Krausmann reiterates this point and presents empirical baseline data for investigating the urban metabolism of Vienna (Krausmann 2013).

The industrial transformation of urban rivers has been a popular topic in environmental history (see reviews e.g. in Bernhardt 2001 or Tarr 2001 for USA). Large rivers such as the Rhine, the Thames or the Seine (Schott 2007; Porter 1997; Backouche 2008) were the first to be studied in Europe, but recently also smaller urban tributaries such as the Senne and its tributaries in Brussels or the River Lea in West Ham (London) have been investigated (e.g. Deligne 2012; Clifford 2012).

Rivers have been subject to pollution and regulations to mitigate or prevent it long before the industrial revolution. But with the transition from an agricultural to an industrial socio-metabolic regime, the patterns and depth of intervention reached an unprecedented level (Fischer-Kowalski 1997). During industrialization, "rivers were subjected to a new era of modern engineering and rationalization" (Castonguay and Evenden 2012, p. 2). The history of the Senne in Brussels as described by Deligne (2012, p. 18) highlights this new role and perception: "when demographic growth and industrialization were generating new ways of devising and amalgamating the territory, the river and the streams no longer ranked as essential components: they could, and sometimes had better disappear".

Urban rivers are ideal sites to study pollution resulting from various crafts and industries. Degrading water quality due to increased waste and wastewater discharge along with population growth and the settlement of industries along the riverbanks has often been analyzed in relation to the countervailing force of the sanitary movement in 19th century Europe (e.g. Büschenfeld 1997; Winklhöfer 2007). Billen et al. (1999) have shown for Brussels and Paris that researchers have long underestimated how much nutrient pollution in urban rivers came from industries. Their research shows that the amount of phosphor and nitrogen released e.g. by tanning or soap production might have been higher than domestic input. It is therefore important to continue investigating the contribution of crafts and industries to the pollution of urban rivers.

Rivers clearly facilitated, supported and limited urban and industrial growth (Castonguay and Evenden 2012). They also determined the spatial organization of cities although thorough investigations of the link between topography, hydro-morphology and the ecology of river systems and urban space are generally rare (for Montreal see e.g. Castonguay and Dagenais 2011).

In this paper, we trace the transformation of the Wien River and the Wien valley from the late 18th to the beginning of the 20th century. We conceive of the Wien River as a socio-natural site (Winiwarter and Schmid 2008; Winiwarter et al. 2013). Socio-natural sites arise from the interactions of human practices and material arrangements. All human actions and material objects are understood as simultaneously natural and social. Practices are routinized actions that are embedded in both social structures and material arrangements on which they depend. Arrangements are both conditions and consequences of 
practices, leading to legacy effects sometimes long after a practice has ceased. Socionatural sites are thus created by human practices but remain subject to biophysical dynamics.

We investigate selected water-dependent commercial uses along the riverbanks and in the catchment and concomitant changes in the spatial distribution of various crafts and industries as changes in socio-natural sites. Detailed studies of slaughtering and the processing of animal parts, the production of chemicals, tanning, beer brewing, and textile dyeing and printing elucidate the diversity of water uses on the Wien River. The valley exhibits three distinct sections. We trace their integration into the urban economy over time. Differences between the lower river section close to the historical center and the upper section, which at the end of the 18th century was still a rural and remote area from the viewpoint of Viennese citizens clearly had an impact on their further development. We also discuss the main drivers of transformation of the socio-natural site Wien River against the background of previous studies, for instance on the sanitary movement (Büschenfeld 1997; Winklhöfer 2007), on industrial growth (Castonguay and Evenden 2012) or on demographic growth (Deligne 2012). Industrialization, the composite process of implementation of large industries, new technologies and infrastructures is a focal point of this study. It is often assumed that modernization and industrialization aim at increasing control over nature and decreasing dependence on it (see e.g. Kaika 2005). Technological changes in water supply and waste water discharge lead to an increasing independence of industries from the direct use of the river. A new spatial distribution of ways to use water was one of the consequences (Swyngedouw et al. 2006). Our study aims at demonstrating that the interdependence between natural endowments, such as hydrological, geological and topographical conditions of a river basin, and technological change did not diminish over time, but changed in character.

The Wien River is a torrential river. Its dangerous floods and periods of water scarcity have influenced siting decisions and posed challenges to the regulation of the river. These dynamics, together with the attempts to "tame" the river, have to be taken into account when analyzing the changing role of the river for crafts and industries. Developments took place at different times along the river, and different driving forces led to different situations in three clearly identifiable sections along its course. A more complex narrative results, a narrative that can help to understand distinct patterns in urban layout and economic structure visible in the city until this very day.

\section{The Wien River as part of Vienna's aquatic network: the study site}

The Wien River is part of Vienna's aquatic network, a network dominated by the Danube (Winiwarter et al. 2013). As a socio-natural site, the urban water network encompasses not only the city's rivers, creeks and its groundwater resources, but among other arrangements also technical infrastructure related to the use of water such as sewers, pipes or groundwater wells. The water network is the result of the long-term co-evolution of the city and its waters above and below ground.

Vienna's surface waters differ with regard to their hydro-morphological dynamics and their spatial location in the city. The Danube crosses the city from the northwest to the southeast (see Fig. 1) and exhibits a high fluvial dynamic due to the prevailing Alpine influence. Vienna is situated in a tectonic basin, the 'Wiener Becken', in which the floodplains spread over $6 \mathrm{~km}$, predominantly on the left banks east of the city center. On 


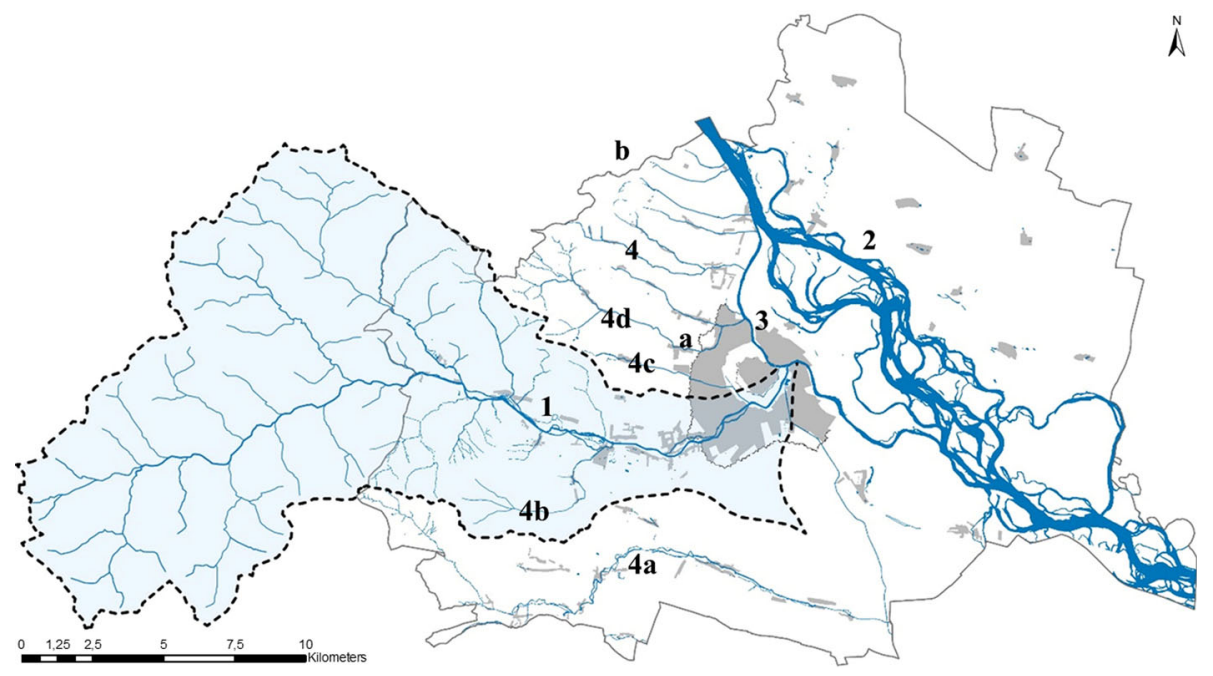

Fig. 1 The Wien River and its location within the urban aquatic network around 1825. 1 Wien River, 2 Danube, 3 Donaukanal, 4 Wienerwaldbäche, $4 a$ Liesing, $4 b$ Lainzerbach, $4 c$ Ottakringerbach, $4 d$ Alserbach, $a$ Linienwall, $b$ present day city limit. Wien River catchment highlighted. Graphic design by Friedrich Hauer based on the Franciscean Cadastre (1817-1829), digitized by Stadtarchäologie Wien

the west side, a Pleistocene terrace (Stadtterrasse) forms a natural barrier. Prior to the systematic channelization between 1870 and 1875, the Danube had several arms. Only the southernmost, the so-called 'Wiener Arm', later Donaukanal, was flowing close to the city and could easily be reached by urbanites. It used to be the main transport route with several landing places and commerce related to transport on both river banks. Other crafts such as tanneries, dyeing works or butcheries existed but their numbers decreased in the second half of the 19th century. They were also found on the tributaries of the Viennese Danube, which discharged from the Vienna Woods' hills in the west (Wienerwaldbäche) ${ }^{1}$. The Wien River is the largest of these tributaries and was thus a prime location for crafts and industries depending on sufficient water supply, and waste and waste water discharge, or on using its hydropower. The other creeks had a mean discharge of $200 \mathrm{l} / \mathrm{s}$ or less and could dry out, especially in summer.

The Wien River rises in the Vienna Woods (Wienerwald) to the west of the town. It crosses present city borders after $20 \mathrm{~km}$ and discharges into the Donaukanal (see Fig. 1). The historical hydrology cannot be reconstructed with certainty, but we assume that prior to the erection of intercepting sewers along the river in the 1830s and the regulation and channelization at the end of the 19th century, mean annual discharge amounted to about $2 \mathrm{~m}^{3} / \mathrm{s}^{2}$ On its (today) $35 \mathrm{~km}$ route, it drops more than $400 \mathrm{~m}$. Hydrology and the rather

\footnotetext{
1 According to hydro-morphological reconstructions (Hohensinner, unpublished), we assume that historically, all tributaries north of the Wien River taken together had an annual mean discharge of around $0.5 \mathrm{~m}^{3} / \mathrm{s}$. The mean discharge of the Alserbach, the largest one after the Wien River amounted to about $0.2 \mathrm{~m}^{3} / \mathrm{s}$.

${ }^{2}$ Unpublished reconstruction by Severin Hohensinner, based on Pollack (2013). Nowadays more than onethird of the $230 \mathrm{~km}^{2}$ catchment is drained by the sewage system of Vienna and not by the Wien River anymore.
} 
steep gradient of about $4.4 \%$ in the urban area (Stummer $1847-1857)^{3}$ made the Wien River most suitable for the use by crafts and factories, and the operation of mills. ${ }^{4}$

However, floods as well as water scarcity posed big challenges to river users. Floods appeared fast and could be big and devastating. The soil in the upper catchment is rather impermeable. This leads to quick runoff of surface waters into the river in case of heavy rain. Since the installation of flood retention basins at the turn of the 19th century, floods which occur statistically every 10 years (10-year return flood) deliver $140 \mathrm{~m}^{3} / \mathrm{s}$, the 100 -year return flood amounts to about $200 \mathrm{~m}^{3} / \mathrm{s}$ (BMLFUW 2011). The biggest recorded floods prior to the installation of retention basins happened in 1785 when several people died and in May 1851 when most bridges were damaged or destroyed.

For economic uses, low water was just as problematic. For example, at the turn of the 18th century, but in particular in 1802, the Wien River had so little water that mills stood still for 8 months (Atzinger and Grave 1874). But even in normal years, discharge was just around $0.4 \mathrm{~m}^{3} / \mathrm{s}$ or even less most of the time. The riverbed was up to $200 \mathrm{~m}$ wide and most of the year, during low and mean flow, large areas fell dry. Smooth operation of mills and other technical edifices required water abstraction into mill channels, enabling better control of the water flow (Hauer et al. this issue).

Except for several weirs and mill streams, only some parts of the river were regulated around 1780: close to the imperial palace of Schönbrunn, the river had been straightened and narrowed and at the Glacis $^{5}$ a stream bend had been straightened. Near settlements, measures were taken to stabilize eroding banks. At the end of the 18th century, the river was winding in some parts. In others, it formed several branches on a broad gravel bed and flat islands covered with plants. There were erosion banks and, primarily, flat banks. Floods could inundate wide areas.

On the passage from the steeper and narrower Wien River valley to the broader and more flat valley near Hütteldorf, bed load accumulated. In case of flooding, the sediment was remobilized and transported further downstream, forming accumulations of gravel of up to three meters. On the one hand, these accumulations contributed to flooding. On the other hand, during low water periods, river water could seep away. However, they formed important habitats for eggs, larvae and benthic invertebrates which survived in the hyporheic zone during dry periods (Reichstein 2016). ${ }^{6}$

\section{Wien River as part of the Viennese water supply}

As the Wien River often carried but little water, access was highly contested, especially for clean water. Water abstraction by mill creeks reduced the discharge in the main river bed. Dumping of waste along the banks and release of waste water caused pollution. In fact, due

\footnotetext{
${ }^{3}$ We thank Christina Spitzbart-Glasl for transcribing documents related to the hydro-geological description of the Wien River (Wienflussaufnahmen) by engineer Josef Stummer. See Spitzbart-Glasl and Pollack. Competition in transition. An exploration of water and land use in the Wien River valley through the eyes of a mid-19th century engineer (in preparation).

4 The Liesingbach in the south was used for mills and other crafts, but it only became part of the city in 1938 and hence, is not further considered here.

5 The Glacis was the artificial terrain outside the fortification wall, which had to be free of buildings and vegetation, created after the first Ottoman siege in 1529. By the end of the 18th century Emperor Joseph II transformed the area into a park like place by planting alley trees and building walkways (Czeike 1992-2004).

6 The hyporheic zone is the subsurface area below the river bottom. It is composed of the sediment and the porous space in-between and stream waters exchanges regularly.
} 
to the low discharge of the Viennese Danube tributaries and their uneven flow throughout the year, crafts and industries - as they needed a constant supply of water for their production processes-depended largely on water supply from wells fed by groundwater. Therefore, water supply from the Wien River cannot be discussed in isolation from the rest of the aquatic network including groundwater.

There is no simple answer to the question of whether or not the situation with groundwater wells was favorable. Between 1817 and 1859, a fire regulation law instructed that every house in the city had to have a groundwater well (Feuerlöschordnung für Wien, $31.12 .1817, \S 10$, in von Barth-Barthenheim 1829). In the 1860 s, more than 10,000 wells still existed in Vienna, abstracting roughly 5601 per site and day ${ }^{7}$ (Stadler 1873). But the existence of a well did not guarantee sufficient supply. In the early 19th century, inhabitants living at higher elevations complained about water scarcity, especially in summer months during longer periods of dry weather (Koblizek and Süssenbek 2003). The hydrogeological situation of Vienna is rather complex and, like a river, has to be viewed as a changing socio-natural hybrid.

Three different types of groundwater were distinguished by geologist Eduard Suess (1862): (1) groundwater from the aquifer connected with the Danube which would rise and fall with the water level of the river, (2) groundwater resources stored under layers of impermeable clayey sandstone (aquicludes ${ }^{8}$ ), and (3) infiltrated rainwater accumulating on top of the impermeable sandstone layer. The water management board of Vienna (WGM, Wiener Gewässer Management) distinguishes several hydrogeological areas in the presentday city with distinctive groundwater conditions (Fig. 2).

In areas of post-glacial alluvial sediments along the Danube (light blue striped) and the small tributaries (blue), groundwater resources were abundant: the groundwater table was high and the aquifer highly permeable due to coarse alluvial sediments. Generally, the younger Pleistocene terraces (yellow) west and south of the historical city feature moderate quantities of groundwater. Further west, in the older and higher Miocene terraces (brown) groundwater availability is reduced due to massive layers of impermeable sandstone acting as aquicludes, a barrier to the flow of water. Such aquicludes also exist below the aquifer of the Pleistocene terraces. Locally, groundwater reservoirs can be found below the impermeable aquiclude. Here, groundwater discharge in form of artesian wells was a typical phenomenon (Suess 1862). Such wells were often located directly below the edges of older terraces, e.g. where the Wien River had cut through the geological basement. The section of alpine bedrock (orange) most remote from the city is characterized by locally widely varying amounts of fissure water. Most of the time only little fissure water is available, therefore this section is not optimal for groundwater extraction. Overall, local groundwater resources played an important role for water supply before the introduction of a network of water pipelines, but it was not distributed evenly in the city.

In addition to surface and groundwater, pipelines supplied water. The first city-wide long-distance water pipeline (Hochquellenwasserleitung) was opened in 1873. It delivered water almost city-wide. Before that, water supply remained decentralized and involved different actors. Pipelines tapping water from the catchment of the Wien River existed at least from the middle of the 16th century onwards (Fig. 3). However, most of them supplied the royal court, while the majority of people depended on groundwater wells

\footnotetext{
7 This number also includes water extracted for irrigating house gardens. The amount was estimated following an inquiry by the city building authority in 1861 .

8 An aquiclude is an impermeable layer above or below an aquifer (Grundwasserstauer). Suess (1862) called this layer Tegel.
} 


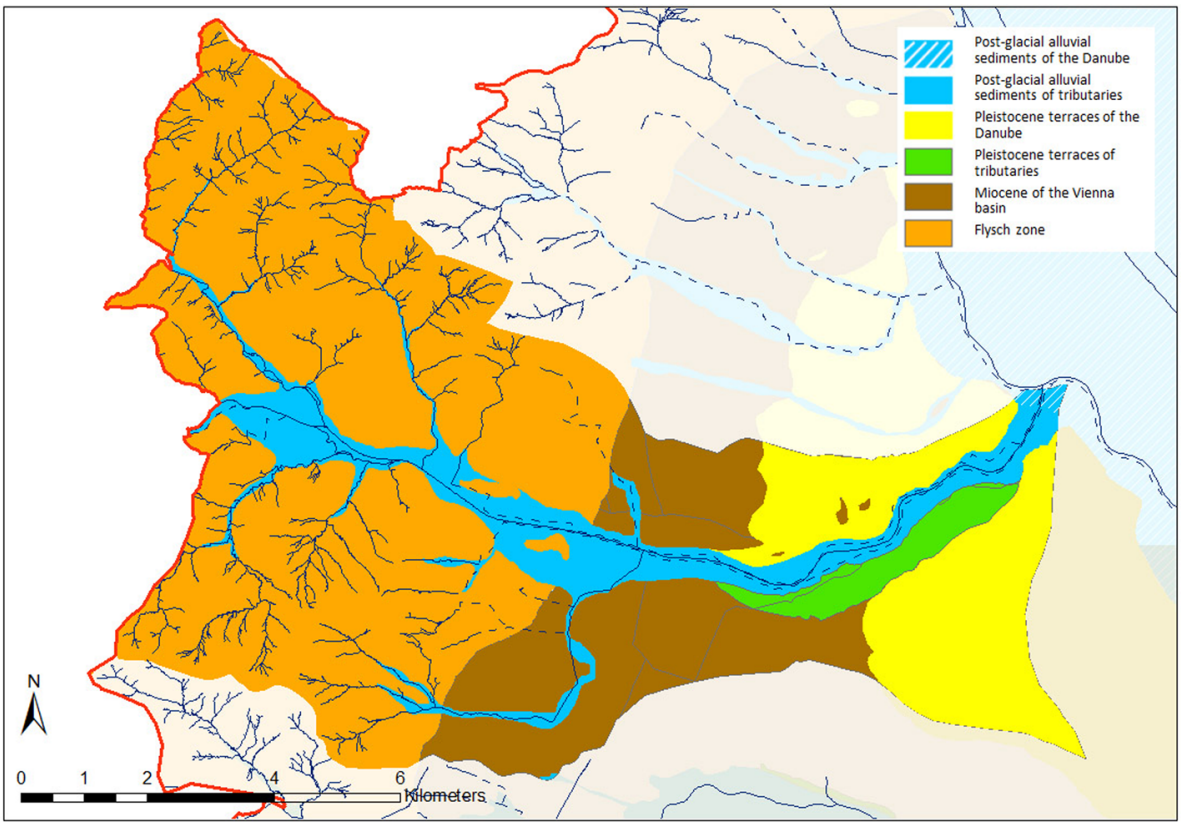

Fig. 2 Hydro-geological map of the Wien River basin within current city limits of Vienna. Source: Wiener Gewässer Management (WGM) on behalf of MA 45, modified by Gudrun Pollack

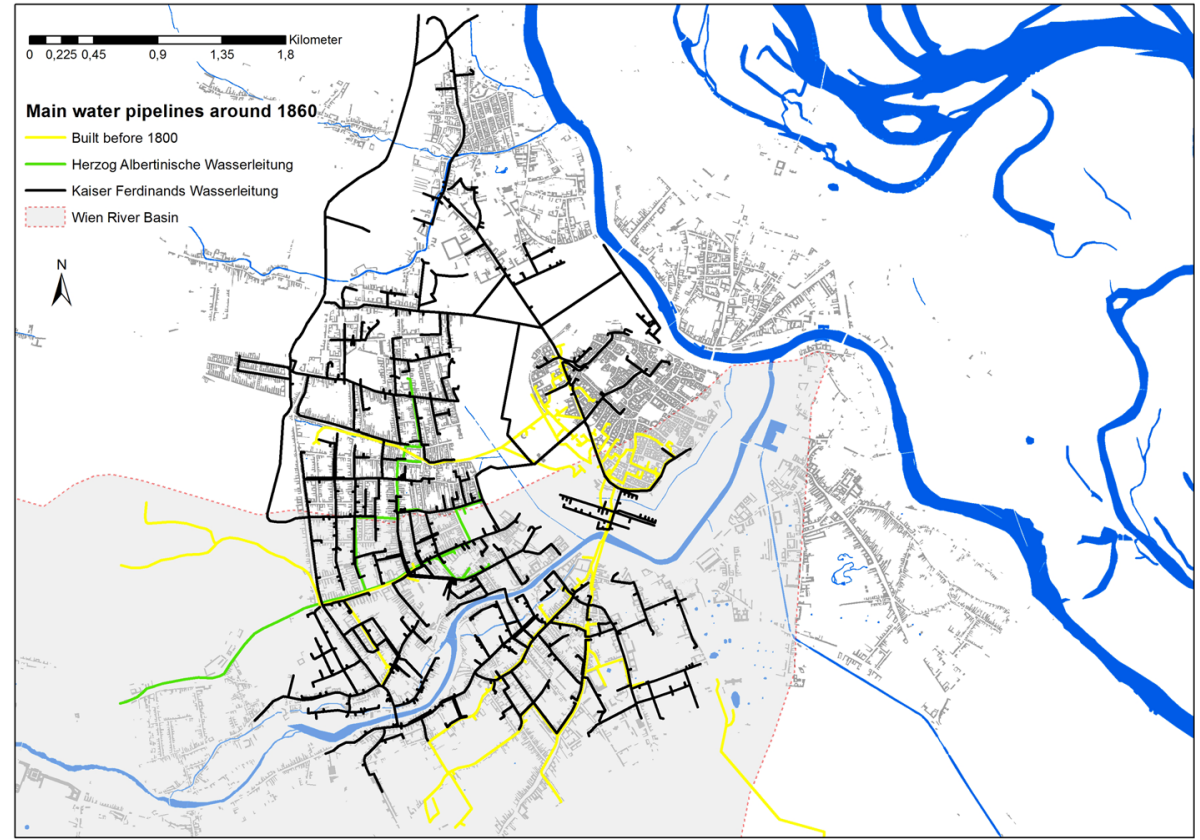

Fig. 3 Main water pipelines in Vienna around 1860. Source: Czeike (ed) (1981ff) Historischer Atlas von Wien. Wasserversorgung 1860; and Franciscean Cadastre (1817-1829), digitized by Stadtarchäologie Wien. Modified by Dagmar Slavicek 
(Meiß1 2001). In 1804, a public water pipeline (Albertinische Wasserleitung) using springs in a sub-catchment of the Wien River was opened (Fig. 3). It provided water for parts of the western suburbs (Koblizek 2005, p. 192). After 1841, a newly built water pipeline, the Kaiser-Ferdinands-Wasserleitung, extracted bank filtrate from the Donaukanal (Fig. 3). It was the first to supply a larger area of the city and the Vorstädte (suburbs), and also parts of the Vororte (villages surrounding the Vorstädte) with water. Water demand had increased after the incorporation of the Vorstädte in 1850 and the city council decided in 1868 to follow the recommendation of geologist Eduard Suess to build a new water pipe. Clean water was tapped from an unpolluted alpine source at the foot of the Schneeberg Mountain almost $100 \mathrm{~km}$ south of the city. Upon insistence of industrialists in the western precincts of the city, which were not yet connected to the Hochquellenleitung, the Wien valley pipeline (Wientalwasserleitung) was built between 1895 and 1898 for process water.

\section{Waste water discharge and pollution of the Wien River}

Before the 1830s-when sewers along Wien River were built-all waste and wastewater, including domestic sewage, was directly dumped and released into the river. The amount of domestic waste and sewage rose with the number of inhabitants. At the end of the 18th century, the inner city and parts of the suburbs already possessed some sewers, which were directly connected to the river. But cesspools were still common. Several decrees prohibited dumping the contents into the Wien River (Pollack 2013, p. 55). A decree of 1824 required buildings to be connected to sewers; cesspools were allowed only when no communal sewer was close (von BarthBarthenheim 1829). Around 1830, $86 \%$ of Viennese houses inside Linienwall, the outer fortification wall, were already part of the $110 \mathrm{~km}$ long network of sewers, which discharged into Wien River and other creeks (Kohl 1905). 3503 houses released their wastewater via sewers into the Wien River and the Ottakringerbach, one of the smaller tributaries that had been diverted into the Wien River (Kohl 1905). An estimated 140,000 people discharged their wastewater and hence, it can be assumed that organic loading and subsequent oxygen depletion from domestic wastewater caused fish kills and serious harm to most other organisms except those especially adapted to cope with low oxygen concentration (Pollack 2013). Pollution from crafts and industry further deteriorated water quality.

The first cholera epidemic in Vienna from 1831 to 1832 led to a turn in city planning with hygiene becoming a major issue. The medical profession saw the polluted Wien River as source of disease and experts observed that areas close to the river and its mill creeks had higher death rates (Knelz 1843). Leaking sewers and cesspools in combination with groundwater as main water source led to a rapid spread of the disease. In 1831, construction of intercepting sewers along both sides of the Wien River between Donaukanal and Linienwall began. After their completion in 1839, they received most of the wastewater between Linienwall and the mouth of the Wien River and discharged into Donaukanal. However, in case of heavy rain, water from the sewers could overflow into the river. In the second half of the 19th century, these sewers were extended to the Vororte closest to the city. In connection with the Wien River regulation at the turn of the century, they were improved and further extended to the new city boundaries in the west. Since the beginning of the construction of sewers, they have discharged both precipitation and wastewater together because sufficient water was needed to flush the waste. 


\section{Regulation of the Wien River}

Floods were frequent and destructive on the Wien River. Technical arrangements at the river such as weirs and mill creeks, as well as the mills drawing on its energy were under threat of destruction and often had to be repaired or re-erected. A more stable water flow was a prime target of planners. At the beginning of the 19th century, discussions about river regulations, pushed by urban health authorities came up again. As main problems to be solved they named "the extensive and widespread course of the river, the rampant sanding-up and siltation of the river bed, insufficiently high banks, the many mills which divert water and block the garbage, the confluences of sewage canals, the discharge of debris and refuse into the river bed, the dragging of sand and clay, finally the insufficient mouth of the river" (Atzinger and Grave 1874, p. 17, translation from German by the authors). As early as the 1780 s, several regulation projects by Wilhelm Bayer and Jean-Baptiste Brequin de Demenge were tabled, but not realized (Atzinger and Grave 1874). Before the extensive regulation of the river at the end of the 19th century, most regulative interventions consisted of stabilizing the river banks, limiting the width, and deepening and straightening the riverbed, e.g. in 1815 within Linienwall. Starting in 1820, works continued upstream, mainly close to the city, but as patchwork of uncoordinated small-scale interventions, because the area was owned and administered by different landlords.

In the mid-19th century, the river was straightened between Karlsplatz and Stadtpark, a city park adjacent to Wien River close to the river's mouth. In connection with the construction of the Westbahn railway line, some regulation work was done in the upper part in the Vororte area, but only as much as was deemed necessary for the railway track. All these interventions were local and, as single measures, did not have much influence on the river's morphology. However, as a whole, they changed the river gradually by stabilizing its course, increasing its flow velocity and diminishing its floodplain.

In the coming decades, bigger regulation plans abounded and discussions continued, often in connection with the idea to construct a railway line in the Wien valley. The most extensive plans went as far as to suggest moving the bed or building a canal for shipping (e.g. Geiger 1875; Atzinger and Grave 1874). None of the plans was implemented, but the river was finally regulated systematically between 1894 and 1904. The sewers intercepting the river were extended, flood retention basins were built, the river was put into a concrete bed and partly vaulted and a railway line was built into the river bed, separated from the river by a wall. The big flood of 1851 with an estimated discharge of up to $600 \mathrm{~m}^{3} / \mathrm{s}$ became the basis for calculating the dimensions of the flood retention basins and the riverbed (Expertenbericht 1882: 73). The extensive regulation-as well as some of the earlier regulative interventions-we perceive as functional segregation, an increasing segregation and relocation of river functions by means of technical infrastructure: The pre-industrial river discharged precipitation and waste, supplied water, and drove mills at the same time. At the industrialized Wien River, these functions either ceased completely (hydropower) or they were taken over by spatially separated arrangements such as sewers (for wastewater discharge), the Wientalwasserleitung (for water supply), flood retention basins and a large concrete river bed (for safe discharge of flood waters) and a railway line in the river bed (transport function). 


\section{Sources and methods}

Our study of the Wien River uses contemporary descriptions of the site, maps produced for different purposes, as well as registers of buildings and locations of various crafts. We chose three points in time-1780, 1825 and 1875-to follow the transformation of the river and the adjacent area from the pre-industrial to the industrial period by focusing on the location of selected crafts.

The GIS-aided investigation of the spatial distribution of commercial production sites along the Wien River for three selected points in time forms the methodological backbone of this study. We used address books, commercial schemes and maps (see Table 1). These sources pose certain limits and inaccuracies, as they were not necessarily produced to give a complete list of production sites. Lehmann (1875), an address book similar to yellow pages, compiled addresses of factories and workshops but also of retail shops or head offices. With respect to the chemical industry, for instance, it was not always possible to distinguish between production sites and shops. However, to cross-check our results, we could draw on maps showing the distribution of industries in Vienna after 1852 (Betriebsstättenverteilung 1852, 1861, 1870/1873, 1880/1890; Historischer Atlas von Wien $1981 \mathrm{ff})$. In contrast to these maps, our study goes back in time to include pre-industrial production, it extends spatially by including the former Vororte, and it includes smaller production sites of crafts.

For the detailed studies, we chose crafts and industries which depended heavily on process water, which contributed to river pollution or were perceived by contemporaries as big polluters and as contributing to the lamentable sanitary situation. The chosen industries are animal slaughtering and processing of animal parts (including tripe butchers and glue production), tanning, textile dyeing and printing, the chemical industry and beer brewing. Beer brewing, dyeing, animal slaughtering and processing of animal parts (which includes

Table 1 Main sources to localize businesses and related problems

\begin{tabular}{|c|c|c|c|}
\hline $\begin{array}{l}\text { Source used } \\
\text { for }\end{array}$ & 1780 & 1825 & 1875 \\
\hline $\begin{array}{l}\text { Spatial } \\
\text { Information } \\
\text { (map) }\end{array}$ & $\begin{array}{l}\text { City map of Nagel (1780/ } \\
\text { 1781) }\end{array}$ & $\begin{array}{l}\text { Franciscean cadastre } \\
\quad(1817-1829)\end{array}$ & $\begin{array}{l}\text { Dritte Landesaufnahme (3rd } \\
\text { Military survey) } \\
\text { (1872-1875) }\end{array}$ \\
\hline Addresses & $\begin{array}{l}\text { De Ponty (1779) for } \\
\text { butchers and chemicals } \\
\text { Löper, Kommerzialschema } \\
\text { (1780) for tanners and } \\
\text { dyeing operations }\end{array}$ & $\begin{array}{l}\text { Redl (1823) and Rittler } \\
\text { (1827) for butchers and } \\
\text { additionally for tanners } \\
\text { and dyeing operations }\end{array}$ & $\begin{array}{l}\text { Lehmann (1875), Dritte } \\
\text { Landesaufnahme (3rd } \\
\text { Military survey) } \\
\text { (1872-1875) }\end{array}$ \\
\hline $\begin{array}{l}\text { Potential } \\
\text { limits and } \\
\text { inaccuracies } \\
\text { of the } \\
\text { sources }\end{array}$ & $\begin{array}{l}\text { Address of house owner } \\
\text { might not always be } \\
\text { address of shop; lists } \\
\text { probably incomplete, } \\
\text { differences in sources } \\
\text { uses }\end{array}$ & $\begin{array}{l}\text { Differences in both sources } \\
\text { used, list might be } \\
\text { incomplete, no addresses } \\
\text { for butcheries outside } \\
\text { Linienwall, probably } \\
\text { incomplete list of } \\
\text { production sites for other } \\
\text { industries outside of }\end{array}$ & $\begin{array}{l}\text { Stock market crash in } 1873 \\
\text { might have had an effect } \\
\text { (but total numbers for } \\
\text { each industry are not } \\
\text { higher before), in case of } \\
\text { chemical industry, } \\
\text { distinction between } \\
\text { production sites and shops } \\
\text { only selling not always } \\
\text { possible }\end{array}$ \\
\hline
\end{tabular}


tanning among others) are crafts with a long tradition. They contributed to organic pollution (resulting in oxygen depletion) and stench, which was-according to the predominant theory of miasmas - considered a threat for health. In contrast, chemical industries produced toxic pollutants often unidentifiable for late 18th and 19th century experts of hygiene. ${ }^{9}$ The range of products was diverse, it changed over time and often had a functional connection to other economic sectors. We focused mainly on products used by the textile industry such as pigments, dyes, bleaches and mordants.

Textile dyers and printers supplied Vienna's textile industry, which became the most important branch of production in Vienna during the proto-industrial phase. Especially luxury production of silk boomed in the 19th century due to skilled workers, sufficient consumers with purchasing power and increasing export. The river was used for washing textiles and dumping dye, which contributed to organic and inorganic pollution. Paper production mainly took place outside of Vienna and along rivers not discharging into Wien River, and hence, was not included.

The area of investigation covers the Wien River and its catchment in present day Vienna. For 1780, it was not possible to localize crafts outside Linienwall. By then this area still had rural character. This changed in the decades to come, as manufactures and factories settled there during early industrialization. Butcheries outside Linienwall could only be identified in the year 1875 . They played a pivotal role for everyday life. Therefore we assumed that in 1780 and 1825 the situation outside the Linienwall was similar to that inside. A register of companies from 1853 supports this assumption (Hahn 1853).

Our three points in time cover the transformation of Vienna from an urban dwelling dominated by an agrarian metabolic regime into an industrialized city (Fischer-Kowalski and Haberl 2007). We draw on maps for the distribution of industries in Vienna (Betriebsstättenverteilung 1906 und 1913; Historischer Atlas von Wien 1981ff) to describe the overall situation at the end point of our investigation around 1910.

\section{Results}

\section{The Wien River sections and their development}

Over the Wien River's course within the limits of present-day Vienna, spatial urban development, i.e. the extension of the town towards south-west took place in three spatially distinct sections with different human uses and impacts on the river at different times. An important factor determining the evolution of these sections was the vicinity or distance to the historical city.

From the end of the 18th to the beginning of the 20th century, Vienna's population within current city limits grew from around 250,000 to more than two million. The number of inhabitants increased markedly also in the Wien River valley, though pace and intensity differed (see Fig. 4).

- Population growth was moderate in the downstream section (A), which comprises the old city center and today's third district on the right riverside. The number of inhabitants grew from 70,000 in 1783 , to 88,500 in $1830,160,000$ in 1880 and to 210,000 in 1910.

\footnotetext{
9 A good overview on early industrial nutrient pollution by crafts and industries is given by Billen et al. (1999).
} 


\section{Population development in Viennese districts adjacent to the Wien River, 1783-2011}

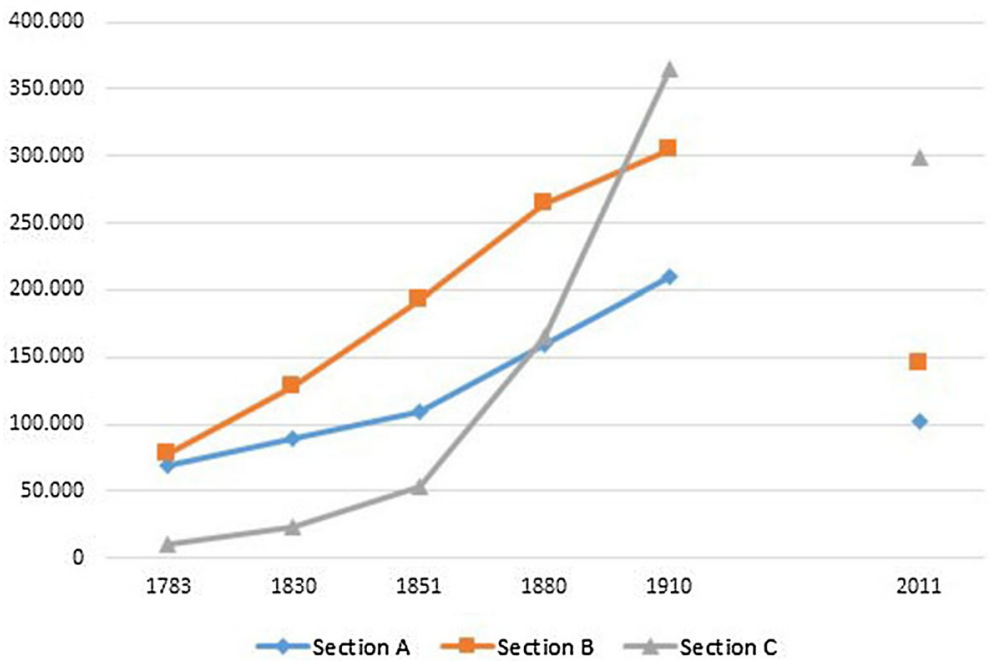

Fig. 4 Population development in several Viennese districts adjacent to Wien River 1783-1910 and 2011. Data from VID (2014) (Ortslexikon), calculations by authors (for section A, we calculated population in the Inner city and the third district, which only partly lie in the Wien River catchment. For section B, we calculated population in districts $4,5,6$, and 7. The seventh district partly lies outside of the Wien River basin. Parts of the tenth district lie in the basin but were not considered for section B calculations. For section $\mathrm{C}$, we calculated population in districts $12,13,14$ and 15 , even though they do not exactly represent the Wien River catchment in section $\mathrm{C}$. The numbers presented approximate the trend of different demographic development in the different areas along the Wien River)

- In section B, the districts between Karlsplatz and Linienwall, incorporated into the urban boundaries formally in 1850, population grew faster than in section A and over the whole period from 1783 until the First World War: 78,000 lived here in 1783, 128,000 in 1830, 264,000 in 1880 and 305,000 in 1910 .

- In the Vororte upstream of Linienwall (section C) the number of inhabitants increased especially in the second half of the 19th century. While population was still low in 1783 with less than 10,000 , it grew to 23,500 in 1830 , to 165,500 in 1880 and 364,000 in 1910.

Following the river course from the mouth upstream, we describe the characteristics of each section (see Fig. 5; Table 2).

Section A: The lowest section of the river between its mouth into the Donaukanal and present-day Karlsplatz, was the unbuilt terrain of the Glacis in front of the fortification walls. This river section had been used intensively in medieval and early modern times but its commercial importance declined as an indirect consequence of the first Ottoman siege. The Glacis had to be kept free of buildings (Czeike 1992-2004). However, a market for selling and buying slaughter cattle existed there until the end of the 18th century.

In 1804, the harbor of an artificial canal to transport wood from forests south of Vienna was completed (Wiener Neustädter Kanal). In 1858, the fortification ring was torn down and prestigious buildings were erected on the former Glacis area (Ringstraße). Along the adjacent lowest section of Wien River, a park, Stadtpark, which exists until present day, 


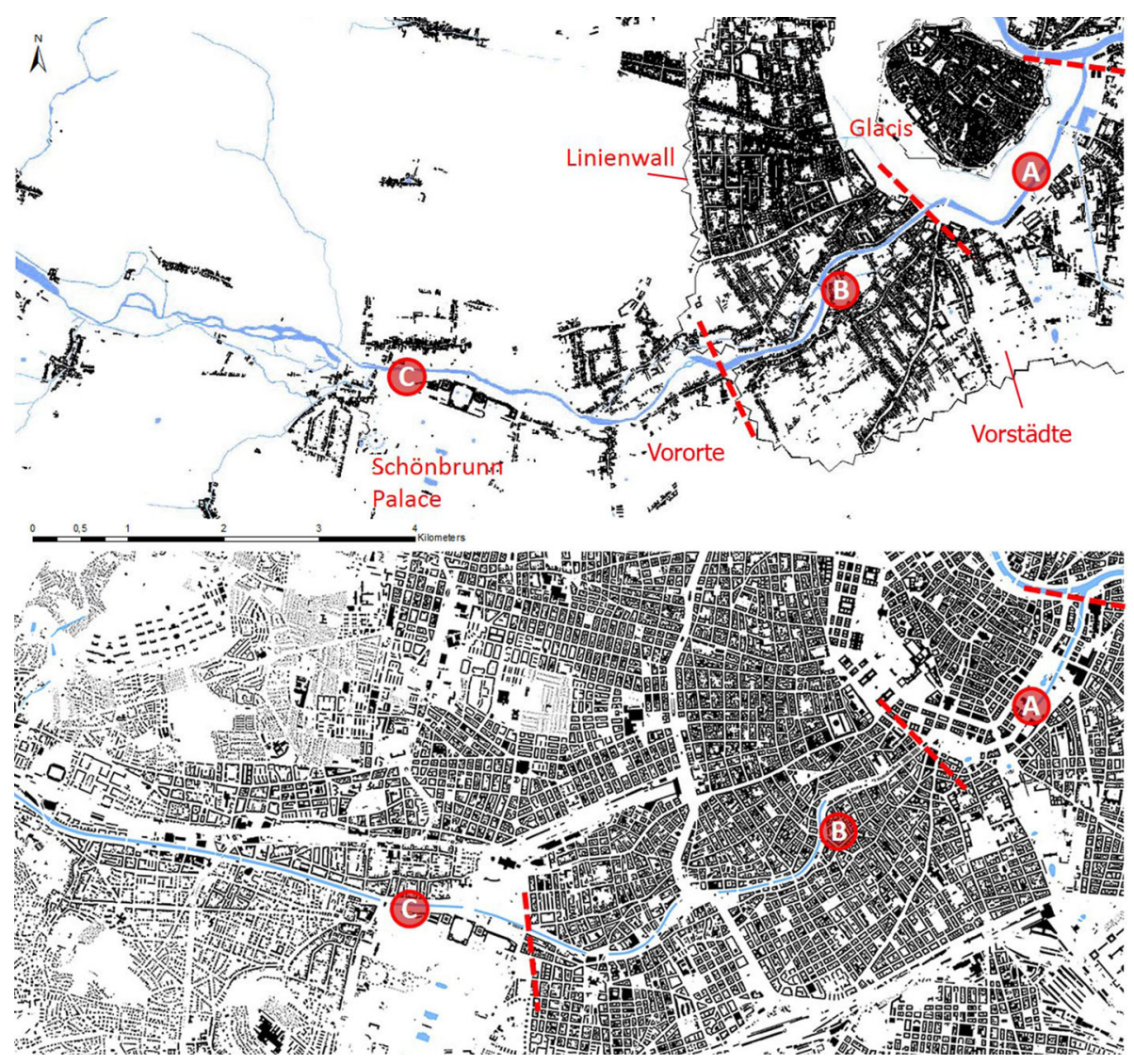

Fig. 5 Transformation of the Wien River valley between 1825 and 2010. Differences in the urban morphology in the three sections $(A, B$ and $C$ ) are still visible today, but the typical pattern of section $\mathrm{B}$ has expanded. Map of 1825 (top): based on the Franciscean Cadastre (1817-1829), digitized by Stadtarchälogie Wien, map of 2010 (bottom): based on the online maps of the city of Vienna and open street maps. Graphic design by Friedrich Hauer

was designed. By 1910, this section of the river had been completely channelized and partly vaulted.

Section B: Between Karlsplatz and Linienwall the Wien River was a major site of preand proto-industrial development. Here the river was flowing through Vorstädte that were - even before their formal integration into the city in 1850 — part of urban taxation and jurisdiction. Since the beginning of the 19th century, the area was densely settled with crafts and workshops clustered along two Wien River mill creeks, which provided the energy for seven mills until they were abandoned between 1847 and 1857 (Hauer et al. in this issue). The area hosted water bound businesses such as tanning, textile dyeing and printing with rather small production sites. Similar to the section downstream (section A), this part of Wien River was channelized and partly vaulted until 1910.

Section C: The third section further upstream, between Linienwall and Hütteldorf, crossed settlements of more rural character, called Vororte. Settlement and commercial development started close to the nucleated villages and, in particular, close to Linienwall. Commercial use of water power on diverted mill streams continued until the 20th century 
Table 2 Overview of the development of the three sections along the Wien River, including the number of crafts and industries, water supply and waste water discharge infrastructure

\begin{tabular}{|c|c|c|c|}
\hline & \multicolumn{3}{|c|}{ Developments and numbers of crafts and industries in each section for 1780,1825 and 1875} \\
\hline & Section A-urban & Section B-proto-industrial & Section $\mathrm{C}$-semirural \\
\hline 1780 & Unbuilt—Glacis & $\begin{array}{l}\text { Residential buildings, crafts } \\
\text { and workshops, mill } \\
\text { streams }\end{array}$ & $\begin{array}{l}\text { Imperial palace of } \\
\text { Schönbrunn, rural } \\
\text { settlements, traditional } \\
\text { uses-e.g. mill streams }\end{array}$ \\
\hline $\begin{array}{l}\text { Crafts and } \\
\text { industries }\end{array}$ & $\begin{array}{l}\text { Slaughtering/animal } \\
\text { processing: oxen market, } 8 \\
\text { butcheries Dyeing- } \\
\text { works: } 1\end{array}$ & $\begin{array}{l}\text { Slaughtering/animal } \\
\text { products: } 31 \\
\text { Dyeing-works: } 9 \\
\text { Tanneries: } 7 \\
\text { Chemical industry: } 4 \\
\text { Breweries: } 3\end{array}$ & $\begin{array}{l}\text { Breweries: } 2 \\
\text { No data availably for other } \\
\text { industries }\end{array}$ \\
\hline $\begin{array}{l}\text { Water } \\
\text { supply } \\
\text { and } \\
\text { discharge }\end{array}$ & $\begin{array}{l}\text { Inner city with water pipes } \\
\text { and sewers leading to } \\
\text { Donaukanal, some sewers } \\
\text { in suburbs discharging into } \\
\text { Wien River, but mainly } \\
\text { cesspools, wells for water } \\
\text { supply }\end{array}$ & $\begin{array}{l}\text { Water supply mainly by } \\
\text { groundwater wells, } \\
\text { pipelines from suburbs to } \\
\text { city, some sewers, often } \\
\text { open, discharging into } \\
\text { Wien River, mainly } \\
\text { cesspools }\end{array}$ & $\begin{array}{l}\text { Wells and cesspools, some } \\
\text { open sewage canals close } \\
\text { to Wien River and } \\
\text { probably dumping of } \\
\text { cesspool content into the } \\
\text { river and tributaries }\end{array}$ \\
\hline 1825 & Unbuilt—Glacis & $\begin{array}{l}\text { Increasing number of crafts } \\
\text { and workshops, mill } \\
\text { streams }\end{array}$ & $\begin{array}{l}\text { Imperial palace of } \\
\text { Schönbrunn; denser } \\
\text { settlements close to } \\
\text { Linienwall; traditional } \\
\text { uses, e.g. breweries, some } \\
\text { factories }\end{array}$ \\
\hline $\begin{array}{l}\text { Crafts and } \\
\text { industries }\end{array}$ & $\begin{array}{l}\text { Slaughtering/animal } \\
\text { processing: } 7 \\
\text { Chemical industry: } 2 \\
\text { Tanneries: } 3 \\
\text { Breweries: } 1\end{array}$ & $\begin{array}{l}\text { Slaughtering/animal } \\
\text { processing: } 55 \\
\text { Chemical industry: } 18 \\
\text { Dyeing-works: } 24 \\
\text { Tanneries: } 14 \\
\text { Textile printers: } 14 \\
\text { Breweries: } 3\end{array}$ & $\begin{array}{l}\text { Chemical industry: } 3 \\
\text { Dyeing-works: } 2 \\
\text { Tanneries: } 6 \\
\text { Textile printers: } 7 \\
\text { Breweries: } 3\end{array}$ \\
\hline $\begin{array}{l}\text { Water } \\
\text { supply } \\
\text { and } \\
\text { discharge }\end{array}$ & $\begin{array}{l}\text { Like } 1780 \text {, but more sewers } \\
\text { and water pipelines }\end{array}$ & $\begin{array}{l}80 \% \text { of houses connected to } \\
\text { sewers or open ditches } \\
\text { discharging into Wien } \\
\text { River, some pipelines } \\
\text { supplying densely } \\
\text { populated parts of } \\
\text { Vorstädte, still many wells } \\
\text { and cesspools }\end{array}$ & $\begin{array}{l}\text { Probably improvements in } \\
\text { sewage canals, especially } \\
\text { close to Linienwall, } \\
\text { Albertinische } \\
\text { Wasserleitung tapping } \\
\text { water in catchment }\end{array}$ \\
\hline 1875 & $\begin{array}{l}\text { 1858: fortification } \\
\text { abandoned } \rightarrow \text { buildings, } \\
\text { park }\end{array}$ & $\begin{array}{l}\text { Increasing number of crafts } \\
\text { and workshops also towards } \\
\text { upstream end, especially } \\
\text { along river and former mill } \\
\text { stream; }\end{array}$ & $\begin{array}{l}\text { Increasing number of } \\
\text { factories }\end{array}$ \\
\hline $\begin{array}{l}\text { Crafts and } \\
\text { industries }\end{array}$ & $\begin{array}{l}\text { Pork: } 5 \\
\text { Chemical industry: } 23 \\
\text { Dyeing-factories: } 2 \\
\text { Tanneries: } 1\end{array}$ & $\begin{array}{l}\text { Gumpendorf slaughter house } \\
\text { Pork: } 71 \text {, Glue: } 2 \text {, Tripe: } 1 \\
\text { Chemical industry: } 50 \\
\text { Dyeing-factories: } 80 \\
\text { Textile printers: } 4 \\
\text { Tanneries: } 12\end{array}$ & $\begin{array}{l}\text { Butcheries: } 11 \\
\text { Pork: } 31 \text { Glue: } 3 \\
\text { Chemical industry: } 15 \\
\text { Dyeing-factories: } 63 \\
\text { Textile printers: } 14 \\
\text { Tanneries: } 22 \\
\text { Breweries: } 3\end{array}$ \\
\hline
\end{tabular}


Table 2 continued

\begin{tabular}{|c|c|c|c|}
\hline & \multicolumn{3}{|c|}{ Developments and numbers of crafts and industries in each section for 1780,1825 and 1875} \\
\hline & Section A-urban & Section $\mathrm{B}$-proto-industrial & Section $\mathrm{C}-$ semirural \\
\hline $\begin{array}{l}\text { Water } \\
\text { supply } \\
\text { and } \\
\text { discharge }\end{array}$ & $\begin{array}{l}\text { Intercepting sewers along } \\
\text { Wien River, decision for } \\
\text { waterborne sewage system, } \\
\text { further improvements, } \\
\text { Hochquellenleitung- } \\
\text { centralized water supply }\end{array}$ & $\begin{array}{l}\text { Like section A, new pipeline: } \\
\text { Kaiser-Ferdinands- } \\
\text { Wasserleitung }\end{array}$ & $\begin{array}{l}\text { Intercepting sewers along } \\
\text { Wien River extend to } \\
\text { densely settled parts close } \\
\text { to Linienwall, further } \\
\text { upstream still direct } \\
\text { discharge into the river, } \\
\text { improvements in water } \\
\text { supply infrastructure } \\
\text { (Kaiser-Ferdinands- } \\
\text { Wasserleitung), but houses } \\
\text { not connected to } \\
\text { Hochquellenleitung }\end{array}$ \\
\hline 1910 & $\begin{array}{l}\text { Wien River partly vaulted, } \\
\text { channelized }\end{array}$ & $\begin{array}{l}\text { Wien River partly vaulted, } \\
\text { channelized }\end{array}$ & $\begin{array}{l}\text { Wien River channelized, } \\
\text { flood retention basins }\end{array}$ \\
\hline
\end{tabular}

in the westernmost part. Between the imperial court at Schönbrunn and a huge boar garden, the Lainzer Tiergarten, courtiers had settled. In the 18th century, small craft shops were few and far between. Industrialization started with larger factories, but much later than in section B, probably due to transportation constraints. During the late 18th and the 19th century, relatively abundant open space and a legal framework different from the densely populated town offered opportunities for business. Businesses were less regulated until 1892 when the area also became part of Vienna.

\section{Spatial distribution of selected crafts in the three sections of the Wien-River}

The GIS-based spatial analysis of selected crafts showed how the number of production sites and their spatial locations changed in the three Wien River sections between the late 18th and the late 19th century (Figs. 6, 7, 8, 9, 10).

In the urban section A the total number of crafts was low and changed only slightly in the investigated time. In 1780 and 1825 we mainly find butchers slaughtering pork and cattle. While their total number remained almost stable, their locations had changed in many cases by 1825 (see Figs. 6, 7). An important site was the oxen market on the righthand bank of Wien River until 1797. It was close to the city, but still outside and with sufficient water for the animals to drink and for cleaning the area from their excreta. Apart from the butchers in 1780 we only found one dyer which had disappeared by 1825 . The types of crafts had diversified by 1825 to include also tanners, chemical production sites and a brewery. In 1875, especially chemical industry had increased, but within the city center these were probably mostly retail outlets.

The development of the proto-industrial section B was more dynamic than that of section A. The total number of production sites approximately doubled in every period from 54 in 1780 to 220 in 1875 (see Table 2). There are, however, clear differences between the crafts we investigated. Especially the number of butchers, dyers, textile printers and chemical production sites grew while the number of tanners and breweries rose only slightly or remained stable. In addition, the locations of the sites changed in many cases from one point in time to the next. The increase of butchers was certainly linked to population growth and continued after 1825, although from 1851 onwards, slaughtering of 


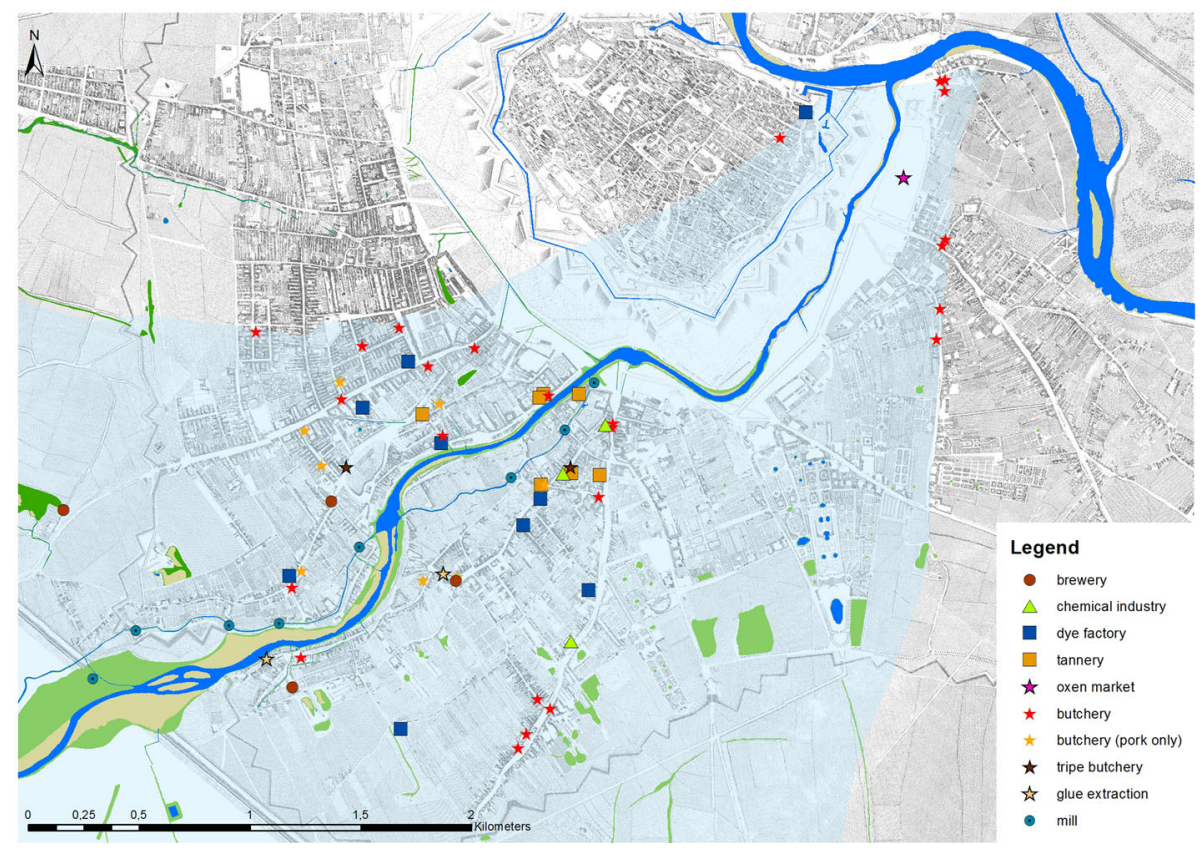

Fig. 6 Location of the selected crafts in sections A and B between Karlsplatz and Linienwall in 1780. Map: City map of J.A. Nagel (1780/81), hydromorphological reconstructions by Severin Hohensinner and his master students

cattle was restricted to one of the two new central slaughterhouses, both erected close to Linienwall. One of them, the Gumpendorf slaughterhouse, was located on the left bank of the Wien River (see Fig. 8). Hygienic considerations, assuring meat supply for a growing population and controlling slaughtering business fostered this decision (k.k. Handelsministerium 1870). Animal slaughtering was closely linked to others crafts: The hide was sold to tanners. After glue extraction, bones rendered fertilizer. Albumin was produced directly in the Gumpendorf slaughterhouse. ${ }^{10}$

For dyers and textile printers the Wien River was a preferred place. Besides access to surface water and water pipelines, the vicinity to the centers of textile production at Schottenfeld and Gumpendorf was important (Banik-Schweitzer and Meissl 1983). Starting in the second half of the 18th century, factories for textile and especially silk production were established there and boomed around 1800 due to exemptions from regulations by guilds, protectionist politics of Joseph II and increasing focus on export. In 1780 all crafts, including dyers and textile printers, were spread over the entire Wien River catchment. Afterwards, however, especially dyers and textile printers moved more and more towards the river and especially to the mill creek on the left river side. Even in 1875, when the mill creek had been abandoned for more than two decades, the concentration of crafts along the former stream not only remained but, quite surprisingly, even increased (see Figs. 6, 7, 8). The reasons for this 'structural permanence' (see Hauer et al. in this issue) may be the close connection to other textile producing industries and some sort of inertia to change

${ }_{10}$ Albumin is a blood protein. It was utilized for different purposes such as making photographic paper, for dye production, or for purifying processes. 


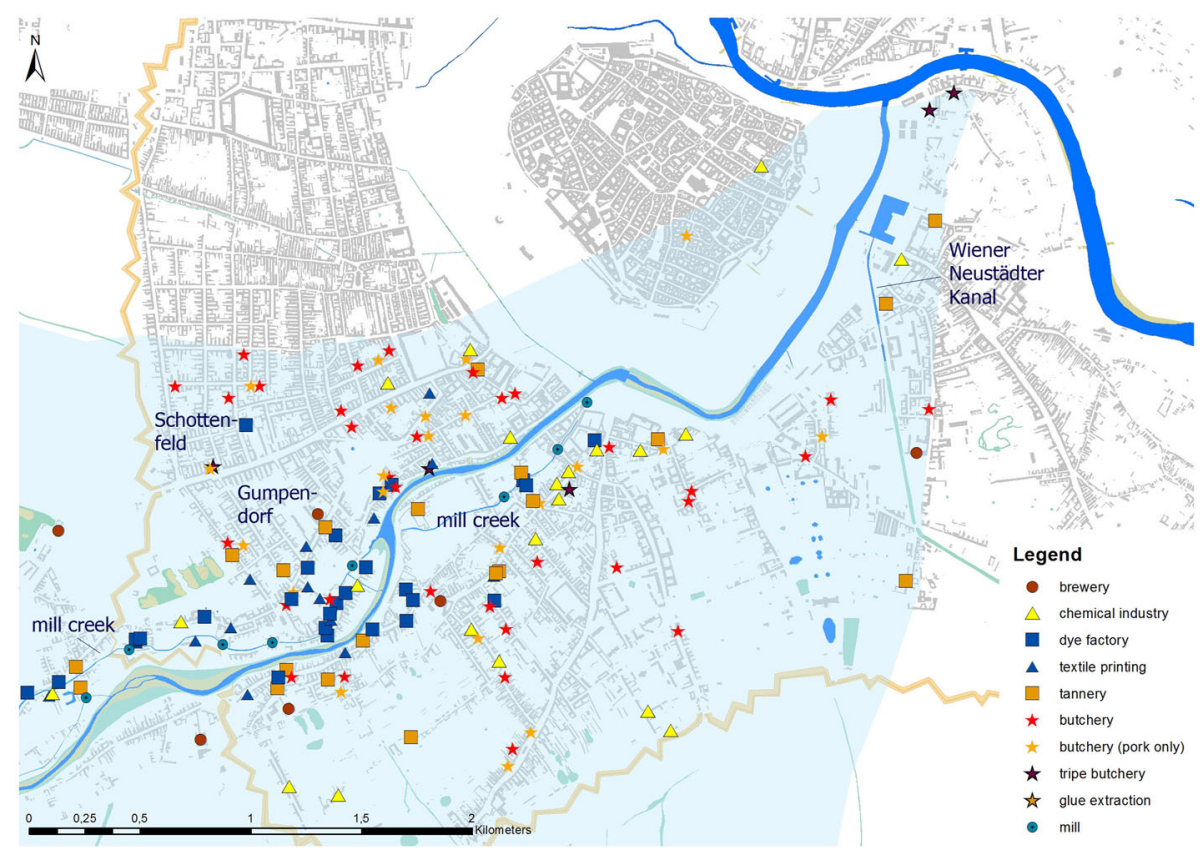

Fig. 7 Location of the selected crafts in sections A and B between Karlsplatz and Linienwall in 1825. Map: Franciscean Cadastre (1817-1829), digitized by Stadtarchäologie Wien, hydromorphological reconstructions by Severin Hohensinner and his master students

'traditional' locations combined with a different source for process water. With increasing urbanization and industrialization, space, especially in section $\mathrm{B}$, became scarce and contested. River regulations, which had deepened, straightened and narrowed the Wien River in this section, had led to a stabilization of the river course. The perceived risk of flooding had decreased despite the huge flood in 1851. This was among the reasons, we assume, why industries moved closer to the Wien River into the floodplains.

Factory-like production of chemicals had started in Vienna by the end of the 18th century. Its growth in the 19th century was among others connected to the boom of the textile industry, which demanded chemically produced colorants, bleaches and mordant such as e.g. Prussian blue and other mineral-based dyes for cloth and textiles. For 1780, several factories existed of which we could locate four, which produced lead white, sealing wax, potash and spirit of soap. ${ }^{11}$ The number of chemical factories increased in section B especially between 1780 and 1825 and thereafter until 1875. In contrast to dyers and textile printers, chemical factories were distributed evenly over the whole area in both points in time, i.e. 1825 and 1875, independently from any access to surface water or water pipelines. The number of tanners did not change much over the investigated time. Three breweries have been identified in 1780 and in 1825 . They were neither located close to the river nor to a water pipeline and their locations did not change. By 1875 they had disappeared and subsequently no brewery existed within Linienwall at that time.

Section C also showed a dynamic development. For 1780 , no sources were available to quantify or locate the enterprises except for two breweries. In 1825, the number of

11 The sources mention a few more factories, but without exact location. 


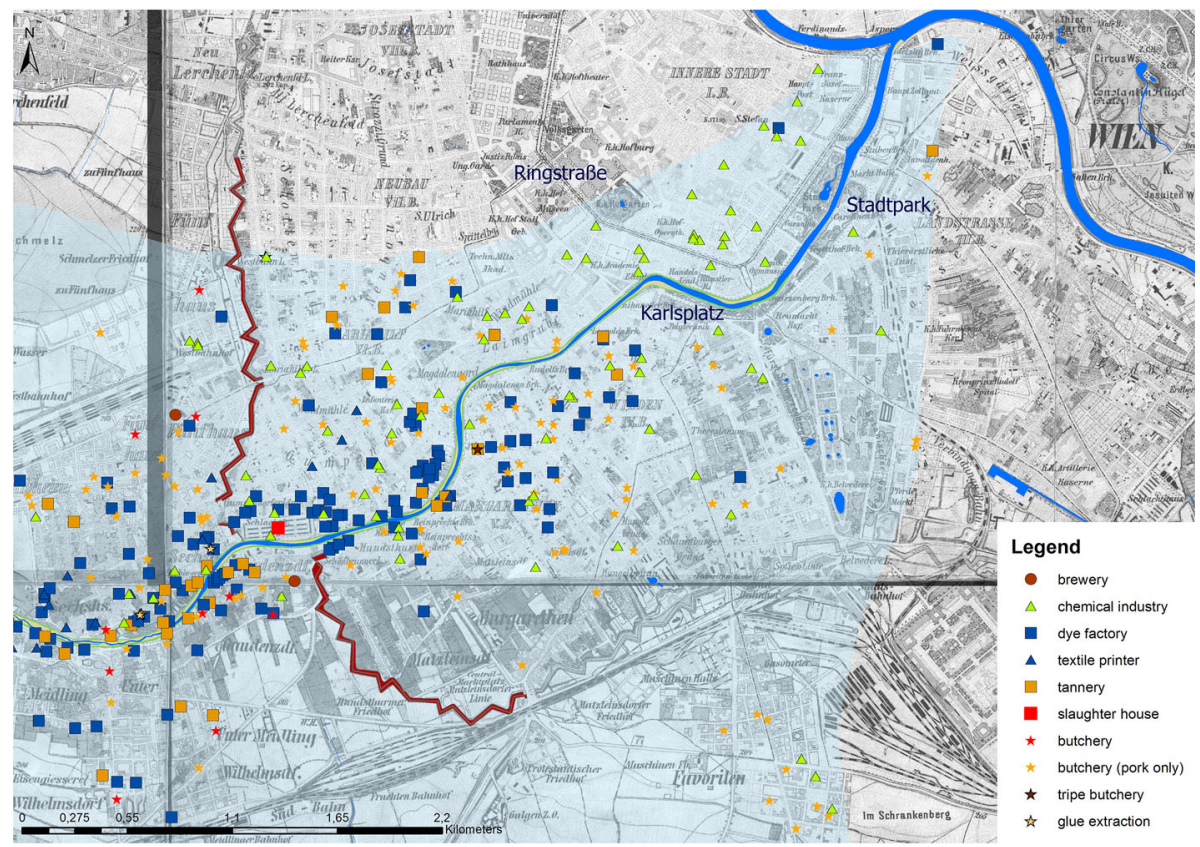

Fig. 8 Location of the selected crafts in sections A and B between Karlsplatz and Linienwall in 1875. Map: Third Military Survey (1872-1875), hydromorphological reconstructions by Severin Hohensinner and his master students

workshops and factories was still low especially compared to section B (see Fig. 9). In total, the number of production sites in section $\mathrm{C}$ grew in from 21 in 1825 to 162 in 1875 (see Figs. 9, 10). Dyers dominated quantitatively. In contrast to section B all types of crafts we investigated exhibited a remarkable growth (see Table 2). Butcheries in section C were compiled only for 1875 when we find a total number of 45 sites (including glue production). Most workshops and factories stayed or were established in the more densely populated villages close to Linienwall. We suppose that this was due to regulations aiming at preventing the city itself from pollution, availability of space and shorter transport routes. On the map (Fig. 10) a cluster of different branches related to the textile industry comprising chemical factories, tanners, dyers and textile printers can be identified on the mill creek just across Linienwall. The chemical industry here produced only colorants, which also points to the close connection between the different workshops in this cluster. Further upstream, Hütteldorf brewery and two tanning factories, one of them including a mill, were situated at a mill creek abstracted from the Wien River. Production sites in section $\mathrm{C}$ were usually bigger and closer to the Wien River and its tributaries, such as the Lainzerbach where a factory producing Mitis green, also known as Paris green, an arsenic-based colorant was situated.

In summary, the spatial analysis yielded some surprising results because the selected crafts showed a less close connection to surface waters than expected. Only some crafts and only in some sections production sites were bound to the river or the mill creeks. This was especially true for dyers and textile printers in the 19th century. The results make evident that water supply from further distances ("water carriers"), wells and water 


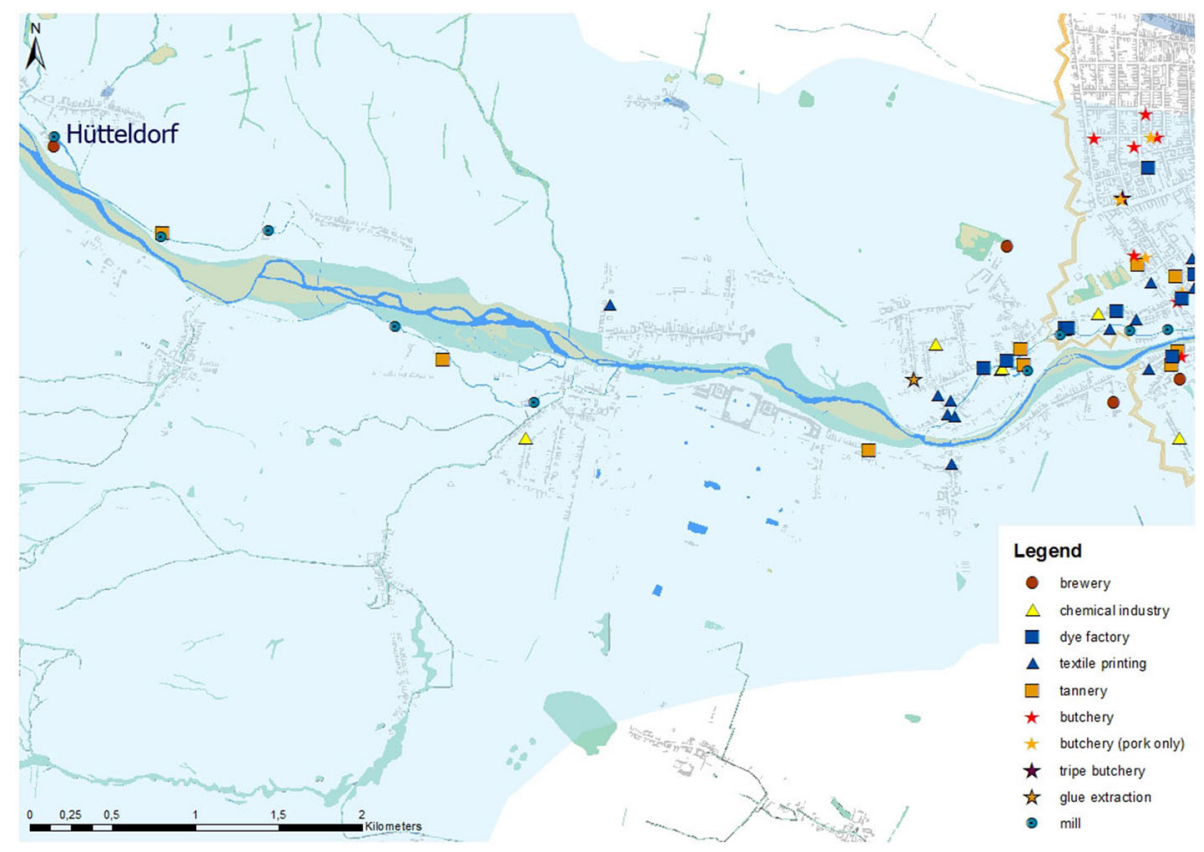

Fig. 9 Location of the selected crafts in section $\mathrm{C}$ in the Vororte outside Linienwall in 1825. Map: Franciscean Cadastre (1817-1829), digitized by Stadtarchäologie Wien, hydromorphological reconstructions by Severin Hohensinner and his master students

pipelines must have been important already in the late 18th and 19th century before the construction of a city-wide water pipeline.

\section{Water use by selected crafts and industries}

Siting decisions in all three sections were based on different factors but surely, water availability and wastewater disposal were among the most prominent for the selected crafts. For all crafts and industries, wells, water pipelines and sewers played a role as important as the Wien River, its tributaries and mill streams. However, textile dyeing and printing were more dependent on river water as they needed large amounts of running water not available before the installation of long-distance water pipelines. To understand siting decisions, technical infrastructure for water supply and waste water discharge as well as other factors such as the perception of industrial pollution or regulations concerning the exertion of industries in the city have to be taken into account.

Maps depicting the spatial distribution of larger industries in Vienna (inner city, Vorstädte and part of the Vororte) from 1852 onwards (Historischer Atlas von Wien 1981ff) show that the Wien River was not the only center of commercial production but the only Danube tributary ${ }^{12}$ with an industrial concentration along its banks. Industries demanding

12 There was also industry important for the supply of Vienna located at Liesing River in the south of the present day city. Throughout our study period, this area was not part of Vienna. Therefore, the Liesing was not included in our analyses. 


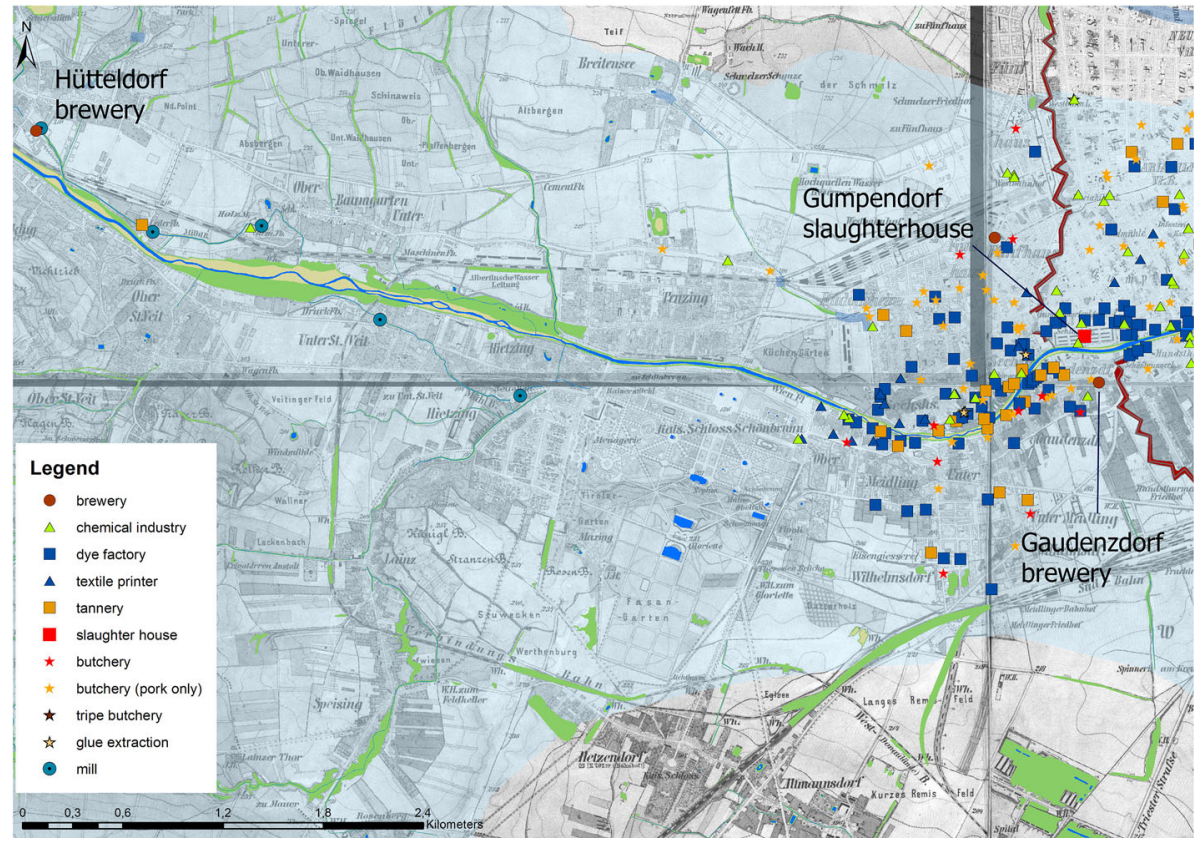

Fig. 10 Location of the selected crafts in section C in the Vororte outside Linienwall in 1875. Map: Third Military Survey (1872-1875), hydromorphological reconstructions by Severin Hohensinner and his master students

large amounts of water and/or space, and big environmental polluters were found only at the Wien River and, to a lesser extent, at the Donaukanal.

For animal slaughtering and processing of animal parts (meat, lard, bones, blood, hide, etc.) water was needed for cleaning tools and working areas and for flushing blood, intestinal content and other wastes. Subsequent and connected processes such as the extraction of animal glue or the removal of big bristles also needed water. Butcheries were initially spread all over the city and were obviously based on decentralized water supply from wells. The slaughterhouse in Gumpendorf, opened in 1851, was connected to the Kaiser-Ferdinands-Wasserleitung, which distributed filtrated water from the Danube to a large part of the city including the incorporated Vorstädte. It is questionable if local groundwater resources would have been sufficient to supply the large facility with its high daily water demand.

Tanners needed large amounts of water and relied on local supply from wells, too. They had to clean the animal skins from urine, blood and other dirt, a task that was mostly done in running water until mid-19th century (Reith 1990; Pierer's Lexikon 1859). Animal skins were soaked in water and water was needed for the subsequent step, the separation of the true skin from the hair. According to an estimate from the 1930s, for $100 \mathrm{~kg}$ of skins about 60001 water were needed (Bergmann and Grassmann 1938). One of the largest tanning companies in mid-19th century Vienna required $13 \mathrm{~m}^{3}$ of water per day (Niederösterreichische Handels- und Gewerbekammer 1855). This would require the water of 26 wells (assuming an average supply of $0.5 \mathrm{~m}^{3} /$ day, Wiener Wasserversorgungskommission 1860). Hence, similar to the slaughterhouse, bigger sites could not solely rely on local groundwater resources but needed external water supply from pipelines. 
Dyers and textile printers needed water for applying colors and removing their residues from the cloth after dyeing. These two crafts show the closest spatial connection to the Wien River and its mill streams because they often used the flowing water directly for rinsing the textiles. Dyers and printers situated further away from watercourses either carried water from the river or brought the textiles to the river; they also used wells and later water pipelines.

The various producers of chemicals manufactured very different products and accordingly, needed different amounts and quality of water. Production of most chemicals requires water, at least for cleaning, and in many cases, clean water is a prerequisite. Our results do not show a very close proximity of chemical production to watercourses even though some factories were located very close to the Wien River, its tributaries such as Lainzerbach or mill streams such as the one diverted from Mariabrunn weir close to today's city limits. We conclude that water supply from wells and pipelines was important for these industries too.

Large amounts of clean water were indispensable for beer production. Hütteldorf brewery was located at a mill stream and also used surface water as energetic resource and for ice production. All other breweries were located at some distance from watercourses. Those within city limits (except for the one in section A) as well as Gaudenzdorf brewery received water from Kaiser-Ferdinands-Wasserleitung, which was opened in 1841/46 and extended several times. Before, local groundwater resources and maybe some earlier local pipelines must have been used to produce beer.

Local groundwater resources and, especially in the 19th century, water from pipelines were more important for the water supply of all chosen industries than the flowing surface water in the Wien River basin, except for textile dyeing and printing. Use of these watercourses for water supply seems to not have been a prime factor for siting decisions. Wells must have played an important role. But growing numbers and size of industrial production sites meant higher demand for water and, thus, increasing pressure to find alternative ways of water supply to become more independent from local groundwater resources.

The Kaiser-Ferdinands-Wasserleitung as well as the Hochquellenleitung offered such solutions, but section $\mathrm{C}$ was only partly connected to urban pipelines until it became part of the city's administration in 1892. Industrialists in the Vororte of the Wien River valley therefore demanded the construction of a water pipeline for process water using water from the Wien River catchment since the 1870s. Four reservoirs at the confluences with tributaries in the rural part of the basin were planned. After almost 30 years of negotiations, the pipeline and one reservoir were built. It was opened in 1898 and delivered up to $25,000 \mathrm{~m}^{3}$ of process water per day to the western part of the city, which corresponds to about $0.3 \mathrm{~m}^{3} / \mathrm{s}$, today's low water discharge of the Wien River. ${ }^{13}$

\section{Wastewater and pollution by selected crafts and industries}

Throughout our study period, the Wien River was intensively used for the disposal of waste and discharge of wastewater from households and industries. Despite the emerging and extending network of sewers, water pollution intensified during the 19th century due to

\footnotetext{
13 Around 1910, more than 300 houses and around 170 hydrants were connected. When the pipeline was abandoned in early 1964, it had been reinforced to an average annual capacity of $7.2 \mathrm{~m}^{3}$ (Czeike 1992-2004).
} 
population growth and growth in production sites especially in section $\mathrm{C}$, which was only gradually connected to the intercepting sewers.

The river contained a cocktail of oxygen depleting substances, bacteria and, increasingly towards the end of the 19th century, organic and inorganic toxins. What was perceived as a pollution problem changed in the 19th century. While foul smells were regarded as dangerous as long as the miasmatic theory dominated, bacteria and other microbes were considered the biggest threat thereafter, a perception certainly triggered by the epidemic outbreaks of cholera. Finally, dependent on developments in chemical analysis in the 19th century, toxic substances were considered dangerous (Büschenfeld 1997).

Until the second half of the 19th century, urban health authorities focused on emissions of organic matter from households and industries. Especially butcheries were discussed by late 18th and early 19th century urban hygienists because of the organic pollution they caused. City physician Mühlibach (1815) gave a vivid description of the bad sanitary conditions in the butcher's stalls, which he considered a major threat to health: "usually there are no wells near these plague-spreading shops. The blood still contained in the smaller vessels of the meat runs down the chopping block to the cobbles of the footpath and further to the street. You run the risk of getting stuck with the shoes when passing by [...] To remove this most injurious threat to health it would be best and safest to construct one large building solely meant for the selling of meat on the Danube, best next to where the fish market is. In any case it has to have access to a sufficient amount of water and the floor, and everything else, except for the chopping blocks and doors have to be made of hard stone" (Mühlibach 1815, p. 106).

He suggested to centralize the operations in one big building close to flowing water to purify the nuisance, a plan that would be realized only 35 years later. When Gumpendorf slaughterhouse started operating in 1851, wastewater was collected in a sewer that discharged directly into the Wien River (Gsandtner 2007). It would later be connected to the intercepting sewer along the river (Historischer Atlas von Wien 1981ff). Cadavers and other animal wastes were buried in the ground between the slaughterhouse and Wien River.

The large number of cattle slaughtered led to a considerable amount of organic matter discharged into the river. We calculated that in the year 1852 Gumpendorf slaughterhouse released about $2 \mathrm{t}$ of blood, $7 \mathrm{t}$ of intestinal content, $3.5 \mathrm{t}$ of skin and horn, $17 \mathrm{t}$ of meat and $3.5 \mathrm{t}$ of bones daily. ${ }^{14}$

Tanneries, dyeing works, breweries, chemical industries and the gasworks across the river from Gumpendorf slaughterhouse were similarly blamed for the pollution of the Wien River (Expertenbericht 1882, p. 41). The water in the millstream downstream Hütteldorf brewery was described as nauseous, stinking and very muddy with a dark color (Expertenbericht 1882 , p. 41). In 1859, the eight breweries operating in the Wien River catchment produced almost 226,000 hectoliters of beer. Assuming production volumes distributed evenly throughout the year, the wastewater discharged daily matched the amount of domestic wastewater produced by ca 21,000 people. $^{15}$

Tanners used potassium and chalk for preprocessing animal skins until the shift from manual to industrial production in the second half of the 19th century. Tanning itself was done on a vegetable basis or with minerals until the 1860s. Most Viennese companiesincluding the largest—used oak bark. Soft and more valuable leather, mainly for gloves or

\footnotetext{
${ }^{14}$ Data on the share of the components of an average oxen are from Hitschmann and Hitschmann (1920).

15 Calculations by authors based on Billen et al. (1999) who suppose an inhabitant equivalent of 35 for 1 hectoliter of beer for the production processes in use at the end of the 19th century.
} 
clothes, was produced with minerals. "Alaun", potash alum, was traditionally used. In 1858, tanning with chrome salts was described for the first time (Bergmann and Grassmann 1938) but it is unknown when Viennese tanneries started chrome-based tanning.

Dyeing of wool and textiles as well as textile printing mostly relied on vegetable substances at the end of the 18th century, although minerals were already used sometimes (Kees 1823-1824). Over the course of the 19th century, mineral-based colorants gained importance. Some colors had to be mixed with other chemicals, as they were waterinsoluble. Urban health authorities criticized polluting practices and imposed fines on textile dyers and printers for using the Wien River despite bans (Innhauser and Nusser 1876). Dyers justified their use of the Wien River pointing out that they had no alternatives. The problem would later be solved with steam-driven pumps and washing machines at the workshops (Innhauser and Nusser 1876).

Chemical producers released toxic substances such as arsenic, lead or chrome into surface and ground water when waste water was dumped or when containers or instruments were cleaned. From the location data, we can infer that toxic substances were present in the Wien River, the mill creeks and some of the tributaries already at the beginning of the 19th century. Color production slowly changed from vegetable and mineral to synthetic (e.g. ultramarine blue after 1858) and aniline colorants, based on coal tar, which also meant that pollutants were changing.

\section{Regulating industrial pollution}

The main reason for contemporaries trying to push enterprises such as dyers or the chemical enterprises out of town was the stench they produced. Police minister Pergen had demanded the prohibition of new factories in Vienna as early as 1794 (Rosener 2004). A decree including this ban was passed in 1795 by the Lower Austrian government, but execution was limited and the ban was criticized by more liberal political actors who favored industries in Vienna in order to foster economic growth. In 1802, another decree was passed. It prohibited the establishment of new factories in Vienna and its suburbs and permitted new industrial sites only outside of the Linienwall. Most prohibitions were abrogated in 1811, but remained in force for some time for chemical production sites (Rosener 2004).

When a regulation of the Wien River started to be more widely discussed in the 1870 s, its pollution was among the main arguments for an all-embracing transformation (see e.g. d'Avigdor 1873; Expertenbericht 1882). Discharging chemicals was perceived controversially at the end of the 19th century, as they could kill microbes in the river and therefore were sometimes attributed cleaning or neutralizing effects. ${ }^{16}$ Urban health authorities report of an order to pour ferrous sulfate into the Wien River at the Linienwall as deodorization measure (WSTP 1874, p. 7). In 1885, businesses such as the parchment factory or soap manufacturers came under fire, because their wastewater ruined the sewers. By then, removing industrial effluents from the Wien River was already connected to debates about the regulation of the river. When the Government of Lower Austria planned to ban the entrepreneurs of the Viennese Vorstädte along the Wien River from releasing any waste and wastewater into the river in 1887, protests ensued. The entrepreneurs fought successfully against these plans (Gerber-Courier 1887, 1-3). Pollution limited the use of river water especially for processes which needed cleaner water. The channelizing and

$\overline{16}$ Steinberg (2004, p. 205 ff.) has pointed that out for New England. 
partly vaulting of the river at the turn of the century, however, limited access to the river and, hence, put an end to the direct use of the river.

\section{Conclusions}

We hypothesized that industrialization would result in increasing independence of waterbound crafts and industries from the Wien River and its local environmental conditions. Hence, we assumed that production sites would be located closer to the Wien River (its tributaries and the mill streams) before or at the beginning of industrialization and sites would move away from surface waters as the implementation of a city-wide water supply and wastewater discharge infrastructure advanced.

Our results challenged these hypotheses: The spatial distribution patterns of the selected crafts and industries from the end of the 18th to the end of the 19th century in the Wien River basin within current city limits show a more complex picture. Different sections of the river exhibited distinct patterns and so did the various branches. In addition, spatial and sectoral configurations changed over time. Textile dyers and printers were most closely connected to the river and its mill creeks, as they used the river directly for production processes until the end of the 19th century. Concentration of production sites along the river increased throughout the 19th century as their total number increased. For the other branches investigated, the connection to the Wien River was not very close. The torrential character of the river with a high risk of regular and devastating floods alternating with long low water periods can explain this somewhat counterintuitive result. A location too close to the riverbanks was exposed to a big risk of flooding and hence, destruction of home and workplace. Mill creeks offered a more safe, because controlled access to water also in times of water scarcity because most river water was abstracted to these artificial channels. During the proto-industrial period, when only few crafts were situated next to the river, the river was also less regulated. Flood protection did not integrate the reclamation of the floodplains. In the following decades, as the city grew bigger and space became more contested, the river was step by step straightened, deepened, limited in width and its banks stabilized in the urban and proto-industrial sections, and later also in parts of the rural section. Apart from other goals, these measures aimed at flood protection. Even though they were not successful all the time, they led to the perception of the river as safer. Together with scarcity of available space due to population growth and industrialization, this can explain why the concentration of production sites close to the river increased during the 19th century.

The Wien River was more important for its discharge function than for water supply and the early construction of sewers leading to the river or, later, to interception sewers also enabled crafts and industries to release wastewater into the river without being located near the riverbanks. Availability of water or supply and discharge infrastructure did play a role for siting decision, but spatial distribution of production sites as well as changes in locations resulted from an interplay of several factors which include e.g. regulations concerning the exertion of industries or administrative boundaries.

For water supply, groundwater played a much more important role than the river water. Water supply shifted from local groundwater resources to pipelines tapping water from some distance. Concentration processes in all trades led to new demands for water. Local over-exploitation (in terms of quantity and quality) of groundwater resources fostered alternatives in the form of longer-distance water pipelines. Hence, dependence on local 
resources decreased, but water tapped within the Wien River catchment was used for water supply throughout the study period and even gained importance at the turn of the 19th century with the construction of the Wientalwasserleitung. With regard to the use of the Wien River for waste and waste water disposal, construction and continuous extension of intercepting sewers and, in general, the implementation of a waterborne sewage system meant decreasing dependence from the use of the river. However, river water was and is still needed to flush away excreta and other waste from the underground sewers. The creation of a networked city as well as alternatives to water power allowed for originally water-bound operations to move away from rivers.

Industrialization, urbanization, massive population growth as well as fundamental changes in production processes and products of many industries led to changes that affected the Wien River and its role for crafts and industry.

Industrializing this urban river meant an intensification of its use and abuse, especially for removing effluents. It also meant increasing functional segregation. This stabilized certain functions with the help of long-lasting arrangements but limited others. The construction of a partly vaulted concrete bed, for example, has modified ecological processes in the long term as it reduces habitats for aquatic flora and fauna and hence, limits biodiversity or the self-purification capacity of the river, i.e. the ability of aquatic organisms to reduce organic pollution.

Industrialization also changed the perception of the river and its meaning in the growing city. For planners and engineers surface waters became (trans-)formable or even removable. The river and its basin were to be adapted to the needs of a fast growing agglomeration, to industrial production, and to the image of a healthy residence city. Vaulting of many of the smaller Danube tributaries in Vienna started already in the 1840s. The Wien River was more resistant to regulations due to its highly dynamic flow regime. It took many years of studying and measuring the river and many regulation proposals until the large-scale regulation was agreed upon. Engineering knowledge and the availability of coal to power machines were an important prerequisite for the large-scale regulation.

Acknowledgments This paper is a product of URBWATER - Vienna's Urban Waterscape 1683-1918. An environmental history. FWF Austrian Science Fund grant no. P25796-G18.

Open Access This article is distributed under the terms of the Creative Commons Attribution 4.0 International License (http://creativecommons.org/licenses/by/4.0/), which permits unrestricted use, distribution, and reproduction in any medium, provided you give appropriate credit to the original author(s) and the source, provide a link to the Creative Commons license, and indicate if changes were made.

\section{References}

3rd Military Survey (1872-1875), Scale 1:25.000, original maps in Bundesamt für Eich- und Vermessungswesen, Wien

Atzinger F, Grave H (1874) Geschichte und Verhältnisse des Wien-Flusses sowie Anträge für dessen Regulirung und Nutzbarmachung, mit Rücksichtnahme auf die jetzigen allgemeinen und localen Anforderungen. Alfred Hölder, Wien

Backouche I (2008) From Parisian River to National Waterway: the social functions of the Seine, 1750-1850. In: Mauch C, Zeller T (eds) Rivers in history, perspectives on waterways in Europe and North America. University of Pittsburgh Press, Pittsburgh, pp 26-40

Banik-Schweitzer R, Meissl G (1983) Industriestadt Wien. Die Durchsetzung der industriellen Marktproduktion in der Habsburgerresidenz, Wien 
Barles S (2012) The Seine and Parisian metabolism: growth of capital dependencies in the nineteenth and twentieth century. In: Castonguay S, Evenden M (eds) Urban rivers: remaking rivers, cities, and space in Europe and North America. University of Pittsburgh Press, Pittsburgh, pp 95-112

Bergmann M, Grassmann W (1938) Handbuch der Gerberei und Lederfabrikation. Springer, Wien

Bernhardt C (2001) Environmental problems in European cities in the 19th and 20th century-Umweltprobleme in europäischen Städten des 19. und 20. Jahrhunderts. Waxmann, Münster/New York

Billen G, Garnier J, Deligne C, Billen C (1999) Estimates of early-industrial inputs of nutrients to river systems: implication for coastal eutrophication. Sci Total Environ 243:43-52

BMLFUW (2011) Hydrographisches Jahrbuch Österreich 2011. Bundesministerium für Land- und Forstwirtschaft, Umwelt und Wasserwirtschaft, Wien

Büschenfeld J (1997) Flüsse und Kloaken: Umweltfragen im Zeitalter der Industrialisierung (1870-1918). Klett-Cotta, Stuttgart

Castonguay S, Dagenais M (2011) Metropolitan natures. University of Pittsburgh Press, Pittsburgh

Castonguay S, Evenden M (eds) (2012) Urban rivers: remaking rivers, cities, and space in Europe and North America. University of Pittsburgh Press, Pittsburgh

Clifford J (2012) The River Lea in West Ham: a river's role in shaping industrialization on the Eastern Edge of nineteenth-century London. In: Castonguay S, Evenden M (eds) Urban rivers: remaking rivers, cities, and space Europe and North America. University of Pittsburgh Press, Pittsburgh, pp 34-56

Czeike F (1992-2004) Historisches Lexikon Wien. Verlag Kremayer \& Scheriau, Wien

D’Avigdor E (1873) Der Wienfluss und die Wohnungsnot: Ein Vorschlag. Ed Sieger, Wien

De Ponty F (1779) Verzeichnis der in der Kaiserlich-Königlichen Haupt = und Residenzstadt Wien, sammt den dazu gehörigen Vorstädten, und Gründen; befindlichen numerierten Häusern. Universitäts Buchdrucker, Wien

Deligne C (2012) Brussels and its rivers, 1770-1880: reshaping an urban landscape. In: Castonguay S, Evenden M (eds) Urban rivers: remaking rivers, cities, and space in Europe and North America. University of Pittsburgh Press, Pittsburgh, pp 17-33

Expertenbericht (1882) Bericht der vom Gemeinderathe der Stadt Wien berufenen Experten über die Wienfluß-Regulirung im August 1882. Verlag des Gemeinderaths-Präsidiums, Wien

Fischer-Kowalski M (1997) Society's metabolism. On the development of concepts and methodology of material flow analysis. A review of the literature. IFF-Institut für Soziale Ökologie, Wien

Fischer-Kowalski M, Haberl H (2007) Socioecological transitions and global change: trajectories of social metabolism and land use. Edward Elgar, Celtenham, Northampton

Franciscean Cadastre (1817-1829) Ed. by A. Behsel, Original maps in Wiener Stadt- und Landesarchiv

Geddes (1915) Cities in evolution: an introduction to the town planning movement and to the study of civics. Williams, London

Geiger T (1875) Wienfluß-Regulirung und Wiener Stadtbahnen nach (seinem) neuen Projecte. Lehmann und Wentzel, Wien

Gerber-Courier (1887, 1-3) Gerber-Courier 12. Februar 1887, Nr. 7, p. 3, Gerber-Courier 19. Februar 1887, Nr. 8, p 2, Gerber-Courier 26. Februar 1887, Nr. 9, p 2

Gsandtner H (2007) Kurzer Abriss der Geschichte der Fleischversorgung Wiens. Lischkar \& Co, Wien

Hahn M (1853) Der Bezirk Sechshaus. Ullreich, Wien

Historischer Atlas von Wien - Betriebsstättenverteilung 1852; 1861; 1870/1873; 1880/1890; 1906/1913: Czeike F (ed.) (1981ff) Historischer Atlas der Stadt Wien. Wiener Stadt- und Landesarchiv - Verein für Geschichte der Stadt Wien, Wien

Hitschmann HH, Hitschmann R (1920) Vademekum für den Landwirt. Moritz Perles, Wien

Innhauser F, Nusser E (1876) Jahres-Bericht des Wiener Stadtfysikates über seine Amtsthätigkeit im Jahre 1875. k.k. Hof- und Universitätsbuchhändler Braumüller, Wien

Kaika M (2005) City of flows. Routledge, London

Kees S (1823-1824) Darstellung des Fabriks- und Gewerbewesens in seinem gegenwärtigen Zustand, vols 1-3. Mörschner und Jasper, Wien

k.k. Handelsministerium (1870) Enquete über die Approvisionierung Wiens. I. Theil: Schlachtvieh und Fleisch. K.K. Hof- und Staatsdruckerei, Wien

Knelz JJ (1843) Darstellung der Brechruhr-Epidemie in der k. k. Haupt- und Residenzstadt Wien. Wien

Koblizek R (2005) Die Albertinische Wasserleitung. In: Brunner K, Schneider P (eds) Umwelt Stadt: Geschichte des Natur- und Lebensraumes Wien. Böhlau, Wien, pp 192-193

Koblizek R, Süssenbek N (2003) "Wasser in jedwedes Bürgers Haus": die Trinkwasserversorgung Wiens. Verein zur Geschichtsforschung, Wien

Kohl J (1905) Die Entwässerung. In: Kortz P (ed) Wien am Anfang des XX. Jahrhunderts. Gerlach \& Wiedling, Wien, pp 193-214 
Krausmann F (2013) A city and its hinterland: Vienna's energy metabolism 1800-2006. In: Singh S, Haberl H, Chertow M, Mirtl M, Schmid M (eds) Long term socio-ecological research: studies in societynature interactions across spatial and temporal scales. Springer, New York, pp 247-268

Lehmann A (1875) Lehmann's Allgemeiner Wohnungs-Anzeiger nebst Handels = und Gewerbe = Adreßbuch für die k.k. Reichshaupt $=$ und Residenzstadt Wien und Umgebung. k.k. Universitäts $=$ Buchhändler, Wien

Löper C (1780) Der kaiserlich königlichen Residenzstadt Wien Kommerzialschema, Vols 1-3. Josef Gerold, Wien

Meiß1 G (2001) Hochquellleitungen und Unratsschiffe. Zur Geschichte der Wiener Wasserver- und Entsorgung. In: Hahn S, Reith R (eds) Umwelt-Geschichte: Arbeitsfelder, Forschungsansätze, Perspektiven. Verlag für Geschichte und Politik, Wien

Mühlibach NT (1815) Wien von seiner übelsten Seite betrachtet. Verlag der Camesina'sche Buchhandlung, Wien

Mumford L (1956) The natural history of urbanization. In: Thomas WL Jr (ed) Mans role change. Face Earth. The University of Chicago Press, Chicago, pp 382-398

Nagel JA (1780) Grundriß der Kayserlich-Königl.en Residenz-Stadt Wien, Ihrer Vorstädte und deren anstoßenden Orte

Niederösterreichische Handels- und Gewerbekammer (1855) Statistische Übersicht der wichtigsten Produktionszweige in Österreich unter der Enns. Leopold Sommer, Wien

Pierer HA (1859) Gerberei. In: Pierer's Universal-Lexikon, Band 7. Altenburg, pp 218-221

Pollack G (2013) Verschmutzt - verbaut - vergessen: eine Umweltgeschichte des Wienflusses von 1780-1910. Social ecology working paper 129, IFF Social Ecology, Vienna

Porter DH (1997) The thames embankment: environment, technology, and society in Victorian London. University of Akron Press, Akron

Redl A (1823) Adressen-Buch der Handlungs-Gremien und Fabriken in der kaiserl. Königl. Haupt- und Residenzstadt Wien dann mehrerer Provinzialstädte. Gollinger, Wien

Reichstein M (2016) Historical hydromorphological changes of the Wien River. Master thesis, University of Natural Resources and Life Sciences Vienna (in preparation)

Reith R (1990) Lexikon des alten Handwerks. Beck, München

Rittler F (1827) Adreß-Buch der ehrsamen Handwerks-Innungen in der k.k. Haupt = und Residenzstadt Wien, für das Jahr 1827. Verlag Leopold Grund, Wien

Rosener R (2004) Chemie in Österreich 1740-1914, Lehre-Forschung-Industrie. Böhlau, Wien

Schott D (2007) Stadt und Fluss: Flüsse als städtische Umwelten im 19. und 20. Jahrhundert. In: Bernd Herrmann (ed) Beiträge zum Göttinge Umwelthistorischen Kolloquium. Universitätsverlag Göttingen, Göttingen, pp 141-162

Stadler R (1873) Die Wasserversorgung der Stadt Wien in ihrer Vergangenheit und Gegenwart. Wien

Steinberg T (2004) Nature incorporated: industrialization and the waters of New England. Cambridge University Press, Cambridge

Stummer J (1847-1857) Wienflussaufnahmen. Wiener Stadt- und Landesarchiv, 3.2.1.1.P1.253

Suess E (1862) Der Boden der Stadt Wien. Braumüller, Wien

Swyngedouw E, Kaika M, Heynen NC (eds) (2006) In the nature of cities: urban political ecology and the politics of urban metabolism. Routledge, Oxon

Tarr J (2001) Urban history and environmental history in the United States: complementary and overlapping fields. Waxmann, Münster, pp 25-39

VID Vienna Institute of Demography (2014) Historisches Ortslexikon. Statistische Dokumentation zur Bevölkerungs- und Siedlungsgeschichte WIEN. http://www.oeaw.ac.at/vid/download/histortslexikon/ Ortslexikon_Wien.pdf. Accessed 3 Feb 2015

von Barth-Barthenheim J (1829) System der österreichischen administrativen Polizey mit vorzüglicher Rücksicht auf das Erzherzogtum Österreich unter der Enns. Bd. 2, J.G. Ritter v. Möslés Witwe, Wien

Wasserversorgungscommission Wiener (1860) Das Wasser in und um Wien. K.k. Hof- und Staatsdruckerei, Wien

Winiwarter V, Schmid M (2008) Umweltgeschichte als Untersuchung sozionaturaler Schauplätze? Ein Versuch, Johannes Coler "Oeconomia" umwelthistorisch zu interpretieren. In: Knopf T. Umweltverhalten in Geschichte und Gegenwart. Vergleichende Ansätze. Attempto, Tübingen

Winiwarter V, Schmid M, Dressel G (2013) Looking at half a millennium of co-existence: the Danube in Vienna as a socio-natural site. Water Hist 5:101-119. doi:10.1007/s12685-013-0079-X

Winklhöfer K (2007) Die Belastung der Spree durch Abwässer aus Fabriken, Gewerbe und der Berliner Mischkanalisation während des Kaiserreichs. Walter de Gruyter, Berlin, pp 303-326

WSTP (1874) Wiener Stadtphysikat 1866-1913: Berichte des Wiener Stadtphysikates über seine Amtsthätigkeit. Braumüller and Verlag des Wiener Magistrats, Wien 